\title{
MENTEŞE/MUĞLA BELEDIYYE BAŞKANI MEHMET RAGIP ZORBAZZADE HAKKINDA 1920 YILINDA AÇILAN USULSÜZLÜK VE YOLSUZLUK SORUŞTURMASI
}

\author{
INVESTIGATION OF IRREGULARITY AND CORRUPTION ON \\ MENTEŞE/MUĞLA MAYOR OF MEHMET RAGIP ZORBAZZADE IN \\ 1920
}

Mehmet TEMEL*

\begin{abstract}
$\ddot{O} z$
1914-1928 yılları arasında Muğla Belediye Başkanlığı görevinde bulunmuş olan Mehmet Ragıp Zorbazzade hakkında fazla harcama, usulsüz sarfiyat, kayıt dışı ve eksik muamele, bütçe dışı harcama, meclis kararı olmadan ve meclis kararından önce işlem yapma vb. gerekçelerle 1920 yılında usulsüzlük ve yolsuzluk soruşturması açılmıştır. Soruşturma sürecinde mülkiye müfettişinin tüm iddia ve suçlamaların cevaplayan Zorbazzade'nin dosyası Dâhiliye Nezareti'nde de değerlendirildikten sonra kanuna aykırı muamelelerde bulunduğu gerekçesiyle hakkında azil kararı verilmiştir. Soruşturmanın, Zorbazzade'nin Muğla'da Kuvâ-yı Milliye'yi, örgütlediği, İzmir ve Nazilli'de toplanan yerel kongrelerde Muğla'yı temsil ettiğgi dönemde açılması Milli Mücadele'ye olan desteğ̈inin kırılmak istendiği şüphesini doğurmuştur. Görevden azledilmemesi ve 1928 yılına kadar sürdürmesi de soruşturma hakkındaki şüpheleri güçlendirmiştir. Bu makalede, soruşturmanın gerekçeleri ve Zorbazzade'nin savunması incelendikten sonra müfettişin iddiaları üzerine bazı değerlendirmeler yapılmıştır.
\end{abstract}

\section{Anahtar Kelimeler}

Muğla, Mehmet Ragıp Zorbazzade, Menteşe Belediyesi, Usulsüzlük, Soruşturma, Kuvâ-yı Milliye

\section{Abstract}

Investigation of irregularity and corruption was initiated in 1920 on Mehmet Ragip Zorbazzade, who served as the Mayor of Muğla between 1914 and 1928, due to causes such as excessive spending, illegal consumption, off-the-books and incomplete treatments, extra-budgetary spending and conducting transactions without the approval of the town council. In the investigation process, the file of Zorbazzade, who replied to all claims and accusations of the civil inspector, was sent to the Ministry of Internal Affairs for investigation, and after the lawsuit, the decision of dismissal was made on the grounds that he had committed illegal acts. As the investigation was initiated when Zorbazzade

* Prof. Dr. Muğla Sıtkı Koçman Üniversitesi Edebiyat Fakültesi Tarih Bölümü, mtemel@mu.edu.tr, ORCID: 0000-0002-95778872 Muğla TÜRKIYE 
organized the National Forces in Muğla, represented Muğla in local congresses organized in İmir and Nazilli and supported the National Struggle; it gave rise to the suspicion that the real aim was to prevent him from. supporting the National Struggle. Although the decision of dismissal was taken, he was not unseated and served as the mayor until 1928, which reinforced the suspicions about the investigation. In this article, after examining the grounds of the investigation and the defense of Zorbazzade, some evaluations were made on the investigator's claims.

\section{Keywords}

Muğla, Mehmet Ragıp Zorbazzade, Menteşe Municipality, Irregularity, Investigation, The National Forces 


\section{GíRIŞ}

Kentlerde yerleşik yaşam sürdüren sakinlerin beledi ihtiyaçlarının karşılanması için tarih boyunca yerel yönetim model ve birimleri oluşturulmuştur. Kamu hizmetlerinin genellikle merkezden taşraya ulaştırılmasına rağmen, belediyelerin hizmeti taşra örgütlerine doğrudan ve hızlı ulaştıılmasını sağlaması nedeniyle katı merkezî devletlerin bile belediyelerden yararlandığı görülmüştür.

Belediyeler, temel kamusal mal ve hizmetleri etkin ve verimli bir şekilde yerine getirmenin yanı sıra yerel demokrasinin gelişimine ve sivil toplum unsurlarının yönetimsel süreçlere katılmasına da katkı sağlamışlardır. Merkezle taşra arasındaki derin refah farkının engellenmesi adına yerel yönetim alanında birçok yenilik yapılarak günümüzün modern belediyecilik anlayışına ulaşılmıştır (Ökmen \& Özer 2013, s.15).

Osmanlı Devleti'nde geleneksel belediyecilik anlayışının egemen olduğu Tanzimat öncesi dönemde belediye hizmetleri vâkıflar, loncalar, kadılık kurumu ve mahalle yönetimi gibi mali özerkliği ve tüzel kişiliği bulunmayan birtakım gönüllü kuruluşlar veya atanmış kişiler tarafından yürütülmüştür (Deniz, Akarçay \& Karakaş, 2017, s.323).

Bu makalenin konusunu, 1914-1928 yılları arasında Muğla'da belediye başkanlığı yapmış olan Mehmet Ragıp Zorbazzade hakkında usulsüzlük ve yolsuzluk gerekçesiyle 1920 yılında açlan soruşturma oluşturmuştur. Ancak, Muğla Belediyesi'nin cumhuriyet öncesi dönemi tarihi, Zorbazzade'nin siyasi yaşamı ve Milli Mücadele'deki faaliyetlerine ilişkin kısaca bilgi verilmesinin de yararlı olacağı düşünülmüştür.

Ege ve Akdeniz sularının kavuştuğu Anadolu coğrafyasının güneybatı ucunda yer alan Muğla Vilâyeti, tarih boyunca belirli sürelerle Leleg, Karia, Lidya, Pers, Atina, Makedonya, Ptolemaios, Selevkos, Rodos, Roma, Bizans, Selçuk ve Osmanlı yönetiminde kalmış, Türkiye Cumhuriyeti döneminde de uygarlıklardan devraldığı tarihi, kültürel, doğal zenginlik ve birikimleriyle varoluşunu sürdüren güzide bir kenttir. Bu kentin modern belediyecilik anlamındaki geçmişi Osmanlı Tanzimat dönemine uzanmaktadır.

Çağdaş yerel yönetim düşüncesinin gelişmeye başladığı Tanzimat döneminde, liva ve kaza merkezlerinde seçilmiş üyelerden oluşan belediye meclisleri oluşturulmasını öngören 8 Ekim 1864 tarihli vilayet nizamnamesi (Ortaylı, 1992, s.400), 1867 yılında çıkarılan, taşra belediyelerinin hukuki ve kurumsal alt yapısıyla fonksiyonların düzenleyen talimatname ve belediyelerin vilayet içinde idari bir varlık kazanmalarını sağlayan 1871 tarihli vilayet nizamnamesinin ardından (Aslantürk, 2018, s.145-146) Muğla' da ilk belediye örgütü 1871 yılında oluşturulmuştur. Bu tarihten itibaren cumhuriyet dönemine kadar Hacı Kadı Süleyman Bey, Hacı Şerif Ağa, Kara Hâfızzade Hacı Mehmet Ali Efendi, Osman Fikri ve Ragıp Zorbazzade belediye başkanlığı görevinde bulunmuşlardır.

Görev yapan belediye başkanları arasında başarıları nedeniyle ödüllendirilen, esnafla çatışmaları nedeniyle görevden alınması için hakkında Dâhiliye Nezareti'ne toplu dilekçe gönderilen ${ }^{1}$, yetkisini kötüye kullanma, hakaret ve hırsızlık suçlamasında bulunma, şahsa ait bir

\footnotetext{
1 Esnafla olan anlaşmazlığı nedeniyle Belediye Başkanı Hacı Şerif Ağa'nın görevden alınması için 5 Temmuz 1907 tarihinde Dâhiliye Nezareti' ne toplu dilekçe gönderilmiştir. Müftünün uzlaştırma çabalarına rağmen esnafın kepenk kapatması ve protestolarla büyüyen olayın soruşturulması amacıyla Aydın vali muavini Muğla'ya gönderilmiştir (BOA, Y.PRK.UM, Dos.79, no.122; BOA, DH.ŞFR, Dos. 383, no.85).
} 
bahçenin duvarını yıkarak belediye binası inşa etme gibi iddialarla yapılan şikâyetler üzerine hakkında Şûrâ-yı Devlet tarafından üç kez men-i muhakeme kararı verilen², kanuna aykırı işlemler yaptığı iddiasıyla hakkında usulsüzlük ve yolsuzluk soruşturması açılıp Dâhiliye Nezareti tarafından görevden azledilmesi kararı verilen de bulunmaktadır³.

Muğla'nın ilk belediye başkanı Süleyman Bey zamanında kuruluş ve kurumsallaşma çalışmalarının yanı sıra saatli kule inşa edilmiş, Soğukdere suyu Muğla'ya getirilmiş, meyvesebze bahçeleri kurularak tarıma öncülük edilmiş, şehir ticaretinin gelişmesi için Yağcılar, Koca Han ve Kıraathane Hanları yaptırılmış, Devlet Hastanesi kurulması için öncü girişimlerde bulunulmuştur (Akça, 2002, s.73-74). Temizlik işlerinde de başarılı çalışmalarda bulunan Süleyman Bey'e Dâhiliye Nezareti, Rabia Ödülü verilmesi için 23 Eylül 1893 tarihinde Sadarete tezkere göndermiştir (BOA, DH.MKT, Dos.137, no.49).

Başkan Hacı Şerif Ağa zamanında şehri Asar ve Kızıldağ gibi yamaç bölgesinden ova yönüne doğru genişletme ve bahçe tarımını geliştirme faaliyetleri yapılmış, dini ve hayır kurumlarının imar ve inşasına, sıhhiyeye yardım yapılmış, Hicaz hattının inşası için travers sağlanmış, traverslerin nakli için yardımda bulunulmuştur4

Kara Hafızzade döneminde de hayır ve vakıf işlerinin yanında cami çevre düzenlemesi, genel tuvalet inşası, çarşı çardaklarının yükseltilmesi, içme suyu ilavesi gibi çalışmalar yapılmıştır (Akça, 2002, s.74). 1890'lı yıllarda 15 mahalle ve yaklaşık 15000 civarında nüfus olan şehirde yıllara göre farklılık göstermekle birlikte 2400 civarında konutun, 342 civarında dükkân ve diğer taşınmazların bulunduğu anlaşılmaktadır (Mete, 2005, C.30, s. 380)5.

Belediye başkanları, bu hizmetleri genellikle sınırlı ve mütevazı bir bütçeyle yürütmeye çalışmışlardır. Bir fikir vermesi bakımından Muğla Belediyesi'nin 1906 yılına ait muvazene cetveliyle 1907 yılı bütçesi hakkında kısa bilgi vermek yeterli olacaktır.

Muğla Belediyesi'nin 1906 yılı muvazene cetveli Mart ayı başından Şubat ayı sonuna kadar devirle beraber emanetler gelirleri 62934 kuruş 10 para, maaş ve masraflariyla emanetlerden ortaya çıkan ödemeler 60442 kuruş 35 para, gelirlerden masrafların düşülmesinden sonra kalan

2 Belediye Başkanı Osman Fikri Bey hakkında yapılan ilk şikâyet, Halilibrahim Oğlu Ziver ve Hacı Karamustafa Oğlu Kemal'e hırsızlık suçlamasında bulunduğu ve iftira attığı iddiasıyla ilgilidir. Ziver ve Kemal adlı kişilerin gazhaneden çalmış oldukları 3 teneke gazın ihbar sonucu yapılan polis tahkikatında dükkânlarında ele geçirilmesi üzerine tahkikat sonuçlanıncaya kadar gaz tenekeleri belediyede koruma altına alınmıştır. Söz konusu kişilerin, Belediye Başkanı Osman Fikri Bey'in kendilerini hırsızlık yapmak ve iftira atmakla suçladığını iddia ederek şikâyette bulunmaları üzerine Menteşe İdare Meclisi başkan hakkında men-i muhakeme kararı vermiştir. Meclisin kararına Liva Cumhuriyet Savcılığı tarafından itirazda bulunulunca dosya Şûrâ-yı Devlet'e gönderilmiş, Şûrâ-yı Devlet de başkan için muhakemeyi gerektirecek bir durum olmadı̆̆ı gerekçesiyle Muğla İdare Meclisi'nin kararını 4 Haziran 1916 tarihinde onamıştır (BOA, ŞD, Dos.1449, no.29).

İkinci şikâyet, başkanın, Hacı Muhsin Ağa Zade Şerif Efendi'nin bahçesine akan suyolunu tahrip ederek Liva Nüfus Müdürü Hasan Efendi' nin hanesine yetkisine aykırı olarak su vermesi ve isale mevkiine gelen Şerif Efendi'nin oğlu Kamil Bey'e hakarette bulunması iddiasıyla ilgilidir. İl meclisinin Osman Fikri Bey hakkında almış olduğu men-i muhakeme kararı, suyoluna müdahale yetkisi olduğu ve hakaretin delili olmadığı gerekçesiyle Şûrâ-yı Devlet tarafından 27 Eylül 1916 tarihinde onanmıştır. Ancak Şûrâ-yı Devlet üyelerinden Abdullah Bey, meydana gelen tecavüzden dolayı şikâyetçinin hukuk mahkemesinde dava açması gerekeceği düşüncesinde olduğuna ilişkin şerh düşmüştür. (BOA, ŞD, Dos.1449, no.38).

Üçüncü şikâyet de başkanın, Hacı Feyzi Efendi'nin kızı Habibe Hanım'ın bahçesinin duvarını yıkarak belediye dairesi inşa ettirmesi iddiasıyla ilgilidir. Bu şikâyet hakkında İl İdare Meclisi'nin başkan hakkında vermiş olduğu men-i muhakeme kararını da Şûrâ-yı Devlet 25 Mart 1917 tarihinde onamıştır. (BOA, ŞD, Dos.1449, no.44).

3 Makalenin konusunu oluşturan Belediye Başkanı Mehmet Ragıp Zorbazzade buna örnektir.

4 Aydın Valiliği Şerif Ağa'nın bu hizmetleri nedeniyle Salise rütbesiyle ödüllendirilmesi için 20 Kasım 1906 tarihinde Dâhiliye Nezareti'ne 288/20 numaralı bir tahrirat göndermiştir. (BOA, DH.MKT, Dos.1140, no.47).

5 Muğla' daki 1889 ve 1894 yıllarındaki taşınmaz malların dağılımı için bkz. (Aktüre, 2006, s.81-82). 
bakiye de 2491 kuruş 15 para olarak gerçekleşmiş ve sandık mevcudu olarak 1907 yılı başına devredilmiştir (BOA, DH.TMIK.S, Dos.72, no.65, Lef.5).

1907 yılı bütçesinde de gelirlerinin 54210 kuruş, kanunlaşmış ve kanunlaşmamış maaşlar ve masraflarının 52744 kuruş olduğu tahmin edilmiş, 1466 kuruş da gelir fazlasının olduğu anlaşılmıştır (BOA, DH.TMIK.S, Dos.72, no.65, Lef.4).

\section{MEHMET RAGIP ZORBAZZADE'NIN HAYATI, SIYYASAL YAŞAMI VE MÍLLİ MÜCADELE’DEKİ FAALIYYETLERİ}

Ragıp Bey 1869 yılında Muğla' da doğmuş, belediye başkanlığı görevine başladığı 1914 yılına kadar tarım, kereste ticareti ${ }^{6}$, üzümcülük gibi ticari faaliyetlerin yanı sıra rakı işletmesi kurmuş ve işletmiş̧tir. İzmirli Jandarma Albay Hüsnü'nün kızı Abide Hanımla evlenmiş ancak eşi genç yaşta hayatını kaybetmiştir. Kendisi de rahatsızlığı nedeniyle tedavi için gittiği İstanbul'da 1928 yılında hayata veda etmiş ve Edirnekapı Şehitliği'nde toprağa verilmiştir (Türkeş, 2019a, s.447; Türkeş, 2019b, s.37,104).

Zorbazzade Ragıp Bey'in siyasal yaşamı ve belediye başkanlığı yılları büyük ölçüde I. Dünya Savaşı ve Milli Mücadele döneminde geçmişti. İttihat ve Terakki kültürü ve bu partinin pratiği içinde yetişen Ragıp Bey (Tekeli, 1993, s.157) partinin Muğla'daki üye ve yöneticileri arasında bulunmuş, Muğla Kuvâ-yı Milliyesi'nin oluşum ve gelişiminde önemli katkıları olan Kardeş Yurdu Kulübü'nün de üyeleri arasında yer almıştır (Türkeş, 1973, s.78,91).

İzmir' in işgalini önlemek amacıyla kurulan İzmir Müdafaa-i Hukuk-u Osmanî Cemiyeti'nin 17 Mart 1919 tarihinde düzenlemiş olduğu toplantıya Muğla temsilcisi olarak katılmış (Akça, 2002, s.9), İzmir'in işgalini takip eden günlerde Yunan ve İtalyan işgallerine karşı mücadele amacıyla 17 Mayıs 1919 tarihinde kurulan Menteşeliler Müdafaa-i Vatan Cemiyeti'nin kuruluşunun öncülüğünü yapmıştır. Muğla'nın önde gelen efe ve zeybeklerinden oluşan ilk silahlı milis kuvvetinin oluşmasına katkıda bulunmuş (Türkeş, 1973, s.255-259; Çanlı \& Türkeş, 1999, s.7-9), cephe gerisi hazırlıklarının tek elde toplanması konusunu görüşmek amacıyla 19 Eylül 1919 tarihinde toplanan II. Nazilli Kongresi'ne katılan Muğla heyetinde yer almıştır (Türkeş, 1973, s.329)7. Güneybatı Kuvâ-yı Milliyesi'nin, Sivas Kongresi kararıyla Garbi Anadolu Umum Kuvâ-yı Milliyesi adı altında toplanıp Ali Fuat Paşa'nın emrine verilmesiyle yeni bir safhaya geçilmiştir (Türkeş, 1973, s.365-366).

1914-1928 yılları arasında Muğla Belediye başkanı olarak görev yapan Ragıp Bey 8 ayrı vali ile çalışmış ${ }^{8}$ ve görevi süresince önemli hizmetlerde bulunmuştur. Alt yapı hizmetleri başta olmak üzere Şemseddin Suyu'nun şehre dağıtımı sağlanmış, mahalle ve çarşı yollarının tamir ve inşası gerçekleştirilmiş (BOA, DH.UMVM, Dos.1, no.92, Lef.1), şehrin içindeki Konakaltı olarak adlandırılan merkez $4200 \mathrm{~m}^{2}$ lik park inşa edilerek genişletilmiş, belediye tarafından sessiz sinema çalıştırılmış (Tekeli, 1993, s.168,163), şehir yerleşim merkezinin güneye doğru genişlemesi sağlanmiştır.

\footnotetext{
Göktepe ve Kozağaç bölgesindeki ormanları işleyen Ragıp Zorbazzade'nin fabrikası 45 beygirlik çeviri gücüyle kente 110 voltluk elektrik de sağliyordu. (Tekeli, 1993, s. 151,164).

7. Ragıp Bey'in Milli Mücadele'ye katkılarından biri de 1921 yılında Söke-Kuşadası semalarında arızalanıp Bağarası Köyü'ne zorunlu iniş yapan Yunan uçağının 57. Fırka Kumandanı Miralay Şefik Aker kontrolünde parçalara ayrılarak Muğla'ya getirilip tamir ettirilmesi ve Sakarya Savaşı'nda kullanılması sürecindeki girişim ve çalışmalarıdır. İsmet Tayyaresi adı verilen uçağın getiriliş, tamir ve yeniden kullanımı süreci için bkz. (Türkeş, 2019b, s.17-19).

8 1914-1928 yılları arasında Muğla' da görev yapmış olan mutasarrıf ve valilerin adları ve görev süreleri için bkz. (Eroğlu, 2011, s. 136; Akça, 2002, s.223).
} 
Ragıp Bey'in Kuvâ-yı Milliye'nin örgütlenmesindeki ve belediye başkanlı̆̆ındaki başarılarının ardında dönemindeki Edhem Fehmi Bey dışındaki mutasarrıf ve valilerle uyum içinde çalışması da bulunmaktaydı. Kuvâ-yı Milliye ve Milli Mücadele döneminde birlikte görev yaptığı mutasarrıflardan Serficeli Hilmi Bey, Atatürk ve Milli Mücadele'ye inanmış, başarılı bir mutasarrıf idi.

İki dönem beraber görev yaptığı Mutasarrıf Müştak Bey de hükümetin takdirini kazanmış bir devlet adamiyd $1^{9}$

Mutasarrıf Hilmi Bey, vatansever, çalışkan, Kuvâ-yı Milliye'yi örgütleyip destekleyen, uzlaştıııcı ve güvenilir bir mutasarrıftı. Belediye Başkanı Ragıp Bey ile vatanın kurtarılmasının yönteminde hemfikir olmuş, başkanla uyum içinde başarılı işler yapmışlardı. İşgal döneminde İtalyanların Muğla ve ilçelerindeki faaliyetlerini izleyerek onların bölgedeki Müslüman ve Rumlar arasında nefret duyguları yaratıp ortaya çıkacak karışıklıktan yararlanarak asker çıkarmaya çalıştıklarına ve ikiyüzlü politika izlediklerine ilişkin 12, 16 ve 26 Nisan 1919 tarihlerinde Dâhiliye Nezareti'ne tahrirat göndermiş, İtalyanların bazı davranışlarını protesto etmişti (BOA, EUM.AYŞ, Dos.6, no. 52, Lef.3,4; BOA, EUM.AYŞ, Dos.3, no. 64, Lef.4).

Ancak Hilmi Bey, Menteşe Mutasarrıfı olarak padişah ve İstanbul hükümetlerinin hoşuna gitmeyen işler de yapıyordu. İzmir'in işgalini protesto için 15 Mayıs 1919 günü Muğla şehir merkezinde yapılacak mitingi "Muğla'nın kahraman evlatlarının istekleri Mutasarrıflı makamının da istekleridir, Mutasarrıflı size muin ve zahirdir. Müsterih olun, teşkilatınızı yapın, icabederse Allah'a kadar yürüyeceğiz ve şikâyetimizi yapmaktan geri durmayacağız" (Türkeş, 1973, s.255) sözleriyle destekleyerek padişahın, gelecek yabancı işgal kuvvetleriyle iyi ilişkiler kurulacak, Türk misafirperverliğine yakışır şekilde karşılanacak, şunun veya bunun tahrik, teşvik ve iğfaline kapılarak misafirlere herhangi bir şekil ve surette muhalefet ve muhasamata girişilmeyecek (Aybars, 1995, s.154-155) şeklindeki emrine karşı çıkıyor, Kuvâ-yı Milliye örgütlenmesine yardımci oluyordu.

Muğla' da basılmakta olan Menteşe Gazetesi'nin 24 Temmuz 1919 günkü 8. sayısı için kaleme aldığı "ihtirâsât-ı beşeriyyeye had ve payan bulunamıyor. Aklın, mantığın bütün edyân ve mesâlikin tanıdığı hakkın tecoiz etmediği garip ahvale şahit oluyoruz. Aydın Vilâyetini Yunanlılar, Antalya ve Menteşe sancaklarmı İtalyanlar işgal ediyor. Niçin, neden, ne hakla? Bu suali kime karşı dermiyan edelim ki aklın, mantığın kabul etmediği, mazinin, hâlin, istikbalin tecviz edebileceğgi cevabı alabilelim..."(Çelebi, 1993, s.225) ${ }^{10}$ şeklinde başlayıp devam eden tarihi yazısıyla işgalleri protesto ediyordu. 19 Eylül

9 Müştak Bey, çalışkanlığı, güvenilirliği ve disipliniyle dikkat çekmiş bir devlet adamı olmalı ki 13 Nisan 1916 tarihinde Dahiliye Nezareti'nden kendisine gönderilen tahriratta Zor Sancağı' nın önemine binaen tecrübesi nedeniyle oraya nakledilmek istendiği ve cevabını acilen bildirmesi istenince (BOA, DH.ŞFR, Dos.62, no.311), 14 Nisan 1916 günü nezarete gönderdiği cevabında görevi kabul edemeyeceğini bildirmiştir (BOA; DH.ŞFR, Dos. 515/101). Bu cevabı üzerine bu kez 18 Nisan 1916 tarihinde bizzat Dâhiliye Nazırı Talat imzasıyla Zor'daki şartlar nedeniyle oraya mutasarrıf olarak gitmesinin istendiğini, gitmekten çekinmeyeceğine emin olunduğunu ve bir an önce hazırlanması gerektiğini bildiren bir tahrirat daha gönderilmiştir (BOA, DH.ŞFR, Dos.63, no.41). Müştak Bey, ertesi günü 19 Nisan 1916 tarihinde çekmiş olduğu cevabi telgrafında bazı durumlar nedeniyle Zor'a gidemeyeceğini, ısrar buyrulursa istifa edeceğini bildirmiştir (BOA, DH.ŞFR, Dos.516/79). Dahiliye Nazırının 1srarlı teklifini reddeden Müştak Bey, emre itaatsizlikten cezalandırılmak veya görevden alınmak yerine 21 Haziran 1916 günü Canik Mutasarrıflığına, (BOA, BEO, Dos.4419, no.331423) 1917 yllinda (BOA, DH.ID, Dos.12, no.17) ve 10 Temmuz 1920 tarihinde tekrar Menteşe Mutasarrıflı̆̆ı'na atanmıştır (Hakses, 2010, s.194). Müştak Bey'in bu döneminde Menteşe Kuvâ-yı Milliyesi tam anlamıyla örgütlenmiş, donatılıp güçlendirilmiş, onun girişimiyle Menteşe Müzaheret Taburları kurulmuş, Denizli' den beraberinde getirdiği Komiser Hamdi Bey'in de çabalarıyla Menteşe polis örgütü güçlendirilip yeniden organize edilmiştir (Türkeş, 1973, s.384-385).

10 Muğla'nın 23 Temmuz 1919 günü işgal edilmesi üzerine Menteşe Gazetesi İtalyanlar tarafından kapatılınca 24 Temmuz günkü sayıda yayınlanacak olan makale yayınlanamamıştır (Çelebi, 1993, s.223). 
1919 tarihinde de 2. Nazilli Kongresi'ne Menteşe'yi temsilen katılmıştı (BOA, DH.KMS, Dos.53, no.54; Türkeş, 1973, s.329).

Mutasarrıf Hilmi Bey'in Padişah ve hükümetleriyle uyuşmayan bu faaliyet, davranış ve düşünceleri cezasız kalmamış, 20 Ekim 1919 tarihinde sadaret emriyle görevinden azledilmiştir (BOA, DH.KMS, Dos.53, no.67; BOA, BEO, Dos.4596, no.344688). Kanuna aykırı davranış ve muameleleri nedeniyle muhakemeye alınması teklif edilmişse de (BOA, DH.KMS, Dos.53-3, no.67, Lef.1) Sivas Kongresi'ne katılmak üzere maiyetindeki iki kişiyle 27 Ekim 1919 tarihinde yola çıkmıştır (Gökbel, 1964, s.392) ${ }^{11}$. Yolculuk güzergâhı hakkındaki kesin bilgi, Konya'daki 12. Kolordu Kumandanlığının, sabık menteşe mutasarrıfı Hilmi Bey'in maiyetindeki iki kişiyle Konya'dan geçtiğini Harbiye Nazırı Cemal Paşa'ya bildiren tahriratından ve Cemal Paşa'nın da 12 Kasım 1919 tarihinde Dâhiliye Nezareti'ne bilgi veren tezkeresinden öğrenilmektedir (BOA, DH.KMS, Dos,53-3, no.67, Lef, 2) ${ }^{12}$.

Belediye Başkanı Ragıp Bey'in belediye işlerinde desteğini gördüğü, Kuvâ-yı Milliye örgütlenmesinde uyum içinde çalıştığı Mutasarrıf Hilmi Bey'in Muğla'dan ayrılmasından sonra Ragıp Bey için de yeni bir dönem başlıyordu. 21 Ekim 1919 tarihinde Canik eski mutasarrıfı Edhem Fehmi Bey Menteşe Mutasarrıfı olarak atanmıştı (BOA, BEO, Dos.4596, no.344688).

Yeni mutasarrıfla belediye işlerinde, Milli Mücadele'yi destekleme ve diğer konularda ilişkiler nasıl seyredecekti? Devlet işleri her zaman ne şekil ve şartlar altında olursa olsun yürürdü. Ancak yerel yöneticiler arasındaki uyum, işbirliği, karşılıklı yardım ve anlayış hem mülki hem beledi anlamda şehrin gelişmesine çok daha katkı sağlardı. 21 Ekim günü atanan yeni mutasarrıfın o günün koşullarında göreve başlamasının bir ayı bulabileceği varsayılırsa 1919 yılı için Muğla' da çevreyi tanıma dışında yapabileceği pek fazla icraatının olmayacağı düşünülebilir.

1920 yılının Ragıp Bey için pek şanslı başlamadığını görüyoruz. Yunan ordusunun Anadolu içlerine ilerleyişi sürerken, İngiliz ve İstanbul'daki yöneticilerin Kuvâ-yı Milliye hareketini güçlenmeden boğmak için yaptığı propagandalar nedeniyle ülkede iç ayaklanma ve karışıklıklar hızla yayılırken, Şubat ayında önüne yolsuzluk, usulsüzlük, keyfi uygulama vs. gibi iddialarla hakkında açılmış bir soruşturma dosyası konuldu.

Herhangi bir ihbar mı yapılmıştı, gerçekten soruşturma gerektirecek icraatı mı vardı yoksa bölgedeki milli kuvvetlere ve Milli Mücadele'ye olan desteği kırılmak mı isteniyordu? Yeni Mutasarrıf Edhem Fehmi Bey'e İstanbul hükümeti tarafından böyle bir görev verilmiş olabilir miydi? Soruşturma açılması yeni mutasarrıfın dönemine mi rastlamıştı? Kuvâ-yı Milliye örgütlenmesindeki başarılı çalışmalarının bedeli mi ödetilmek isteniyordu? Hakkında açılan geniş çaplı soruşturma sırasında sorulan sorular ve iddialara verilen cevaplardan bu soruların cevabı bulunabilir miydi?

Mustafa Kemal Paşa Samsun'a ayak bastığında Canik Mutasarrıflığı görevinde bulunan Edhem Fehmi Bey'in, hastalığı gerekçesiyle Mustafa Kemal'i karşılamayıp yerine Muhasebe Müdürü Osman Bey'i görevlendirmesi (Yazıc1, 1985, s.94-95) Mustafa Kemal'in 20 Mayıs 1919 günü Dâhiliye Nezareti'ne çektiği telgrafta İstanbul'a ailesinin yanına dönmek isteyen Mutasarrıf Edhem Fehmi'nin isteğinin kabul edilmesini istemesi (BOA, DH.ŞFR, Dos.631, no.17), Nutuk'ta

11 Heyette, Nazillili Hacı Süleyman Efendi ile Denizli delegesi Başağazade Yusuf Bey de bulunmaktadır (Türkeş, 1973, s.339).

12 Geç ulaştı̆̆ı Sivas'tan geri dönmeyen Hilmi Bey, Mustafa Kemal Atatürk'ün yanında kalarak Milli Mücadele çalışmalarını sürdürmüştür. Atatürk tarafından Pozantı ve İçel'e mutasarrıf olarak atanmış, Milli Mücadele ve Cumhuriyetin ilk yıllarında da sırasıyla Adana, Diyarbakır, Elazı̆̆, Sivas ve Trabzon valisi olarak görev yapmış ve emekli olmuştur (Türkeş, 2019b, s.36). 
ifade ettiği gibi Samsun'a tanıdık ve kendisinden büyük enerji beklediği bir zatın mutasarrıf atanması talebi (Kemal Atatürk, 2012, s.12)13, Mustafa Kemal ve onun talebiyle mutasarrıf atanan Hamid'in, Edhem Fehmi'yi Rum çetelerine karşı önlem almamak ve silahları teslim etmekle suçlaması (Kemal Atatürk, 2012, s.12; Eken, 1995, s.67-69) onun, Menteşe Mutasarrıflığı sırasında Rumlara ve işgale karşı Canik'te izlediği politikalara benzer davranışları14, I. Meclis'te 2. Grup içinde gösterilmesi (Zeki, 2018, s.69) ve Hürriyet ve İtilafçı olduğuna ilişkin yorumlar vb. birçok neden belediye başkanı Mehmet Ragıp hakkında açılan soruşturmaya ilişkin ipucu verebilir miydi? Soruşturmanın tahlilinden bu sorulara da yanıt bulunmaya çalışılacaktır.

\section{MEHMET RAGIP ZORBAZZADE HAKKINDA AÇILAN USULSÜZLÜK VE YOLSUZLUK SORUŞTURMASI}

Çevresinde ve şehir eşrafı arasında saygın, hatırı sayılır bir kişi olarak bilinen Ragıp Bey, azalık ve başkanlık gibi görevlere de en yüksek oyla seçiliyor, mutasarrıflardan takdir görüyordu. 1917 yılındaki görevine seçilişi de aynı şekilde olmuştu. Menteşe mutasarrıf vekili tarafından 2 Nisan 1917 tarihinde Dâhiliye Nezareti'ne gönderilen tahriratta, 3 belediye azalığı için kanuna uygun şekilde yapılan seçimde halen belediye reisi olarak görev yapmakta olan Zorbazzade Ragıp Bey'in en fazla oyu alarak yeniden seçildiği, güzel hizmetleri ve liyakati nedeniyle başkanlık görevini sürdürmesinin uygun görüldüğü bildirilerek onay talebinde bulunulmuştur (BOA, DH.UMVM, Dos. 90, no.23, Lef.1). Nezaret tarafından Menteşe Mutasarrıflığı'nın 2 Nisan 1917 tarih ve 38301/52 nolu tahriratına verilen cevapta, Meclis-i Mebusan kararıly asli şekline döndürülen Vilâyât-ı Belediye kanununun 4. maddesi gereğince seçilmiş azalar arasından atanmaları gereken belediye başkanlarının, mahallerinin en büyük mülkiye memurları tarafından seçilip atanmaları gerektiğinden üst makamlarca memuriyetlerinin onayına gerek duyulmadığı bildirilmiştir (BOA, DH.UMVM, Dos. 90, no.23, Lef.2).

1917 yılında güzel hizmetleri ve liyakati nedeniyle göreve devamı istenen başkana, fazla ve usulsüz sarfiyat, eksik ödeme ve eksik muamele, kayıt dışı işlem, mühürsüz senetle ödeme, gereksiz birleştirme, bütçe dışı harcama, meclis kararından önce ödeme ve meclis kararı olmadan icraatta bulunma gerekçeleriyle 1920 yılı Şubat ayında soruşturma açılmıştır.

Mehmet Ragıp Bey hakkında mülkiye müfettişi tarafından yürütülen soruşturma ve evrak incelemelerinden 1918 ve 1919 yıllarında yapılan tüm harcamaların, alınan kararların, yapılan muamelelerin en ince ayrıntılarına kadar gözden geçirildiği anlaşılmaktadır. Müfettiş tarafından yapılan genel bir tespitten ve ihtiyaç duyulan dokümanların da belediye yetkililerinden alınıp değerlendirilmesinden sonra usule aykırı bulunan tüm maddelerle ilgili gerekçeli yorum yapılmıştır. Müfettişin iddiaları şunlardır (BOA, DH.UMVM, Dos.1, no. 92, Lef.1).

\section{a. Fazla Sarfiyat}

İtalya Bahriye kumandanıyla maiyetlerine (Bittahkik dört kişi olup bir gece belediye reisi Ragıp Beyin hanesinde misafir kalmışlar ve yalnız bir akşam taamı tenavül eylemişlerdir) 8 Mart 1919 tarihinde verilen ziyafet için 10097,5 kuruş masraf gösterilmiş, bir seferden ibaret olması gereken bu ziyafette Belediye Müfettişi Osman mührüyle mühürlenmiş senede ekli müfredat sarfiyat pusulasindan,

840 kuruşluk beş buçuk kıyye ${ }^{15}$ sadeyağı,

250 kuruşluk 5 kıyye zeytinyağı,

13 Dâhiliye esbak müsteşarı Hamid Bey, Mustafa Kemal'in teklifi üzerine 25 Mayıs 1919 tarihli irade-i seniyye ile Canik Mutasarrıflı̆̆ı'na atanmıştır (BOA, BEO, Dos. 4576, no.343138; Türkmen, 2020, s.179).

14 Menteşe Mutasarrıfı Edhem Fehmi'nin Menteşe' deki Rumlarla ilişkileri için bkz (Umar, 2002, s.149-151).

15 Kıyye: 1282 gramı karşılayan ağırlık ölçüsü (Devellioğlu, 1990, s.621). 
700 kuruşluk 10 kıyye pirinç,

1250 kuruşluk 10 kıyye şeker,

150 kuruşluk 5 kıyye incir,

650 kuruşluk 5 kıyye peynir,

250 kuruşluk 5 kıyye üzüm,

200 kuruşluk 2 kiyye badem içi,

100 kuruşluk 1 kile ceviz,

40 kuruşluk yarım kıyye künar

beher kıyyesi 50'şer kuruştan 250 kuruşluk 5 kıyye ve beher kiyyesi 25'er kuruştan 50 kuruşluk 2 kıyye ki toplam iki defada 300 kuruşluk 7 kıyye kuru fasulye,

232,5 kuruşluk 93 adet yumurta,

1600 kuruşluk ve en az 25 okkalık $^{16} 1$ adet koç,

100 kuruşluk 40 adet portakal,

105 kuruşluk 21 adet limon,

65 kuruşluk 1 adet kavun,

60 'ardan 120 kuruşluk 2 bakraç yoğurt,

90 kuruşluk 4 tabak kaymak,

80 kuruşluk taze soğan ve marul,

80 kuruşluk 2 kıyye zeytin tanesi,

900 kuruşluk meşrubat,

125 kuruşluk yarım kıyye kahve,

190 kuruşluk 2 kıyye sabun,

75 kuruşluk 1 yük çıra,

100 kuruşluk 2 yük odun,

1250 kuruşluk 6,5 kıyye gaz yağı satın alındığı anlaşılmıştır. Söz konusu harcama çok yüksek olmakla birlikte, pusulada kimlerden alındığı müfredatla gösterilen yiyecek, meşrubat ve yakacak için tümünden olmasa bile içlerinden çeşitli şekilde ve 1000 kuruştan fazla tutan alımlardan usule aykırı bir şekilde senet alınmaması da dikkati çekmektedir.

\section{b. Usulsüz Sarfiyat}

Ramazan Bayramı'nda ve onu takip eden cülus-u hümayunda belediyeyi ziyaret edecek kişilere dağıtılmak üzere belediye azasından İsmail Efendi'nin hemşirezadesi tüccardan Seylihazade Salih Efendi'den alınan 6 Temmuz 1919 tarihli senet gereğince 515 kuruşluk 1,5 kilo, milli bayramda belediyeyi günlük ziyaret edecek kişilere dağıtılmak üzere söz konusu kişiden alınan 23 Temmuz 1919 tarihli senet gereğince 360 kuruşluk 1 kilo birinci çeşit sigara satın alınmıştır. Söz konusu kişinin manifatura tüccarından olması nedeniyle sigaraların ondan alınmamış olması gerekirdi. Ziyaretçilerin sırf memur reislerinden ibaret olduğu ve bunların sayısının da elliyi aşmayacağı dikkate alındığında 2500 sigaraya tekabül eden 2,5 kilo sigaranın yarım kilosu kâfi iken 2 kilo fazla alınmıştır.

Miktarı belirsiz sarfiyata ait meblağın usulen avans suretiyle ve pulsuz senetle mutemetlere verilmesi, kimlerden ne gibi şeyler satın aldıklarına ilişkin ibraz edecekleri pullu senetlerin incelenerek ellerinde para kalmış ise geri istenmesi gerekirdi. Ancak teşrif eden heyet-i nasihaya

161 okka $=1282,945$ gr (Kallek, 2007, C. 33, s.338). 
hükümet dairesinde memur reislerinin de dâhil olduğu ziyafet için harcanan 27186 kuruş 30 paranın açıktan sarf sonrası karşılığında mutemet olarak encümen azasından Ethem ve Belediye Sandık Emini Yusuf Ziya Efendilerden müşterek ve pullu senet alınmıştır. Söz konusu senede bağlı el defterinde çeşit ve miktarı gösterilen yiyecek vesaireden bir kaçının hizasına bayilerine ve yedi bin küsür kuruşluğuna, tarafından satın alınan belediye müfettişine sadece imza ettirildiği ve 5722,5 kuruşluğunun hiç imzasız olduğu görülmüştür. Ethem ve Yusuf Ziya Efendilerin bu muamelesine belediye müfettişinin iştirak ettirilmesi, bayilerinden pullu masraf senedi alınmadan adi el defterine kaydedilerek hesapların kabul edilmesi ve kalan meblağın da adı geçen kişilere verilmesi uygun değildir.

\section{c. Eksik Ödemeler ve Muameleler}

Belediye başkanı, sandık emini, kâtip, müfettiş, kalfa ve çavuşlara 500 kuruşa kadar maaşları için Liva İdare Meclisi'nin beher kilosuna 20 kuruş takdir eylediği 30 kilo buğday bedeli olan 600 kuruş pahalılık zammı ve onun \%6'sı nispetinde ekmek bedeli verildiği halde arabacı ve küfecilere aynı muamele yapılmamış, maaşlarının bir misli oranında yani 400 kuruş maaşı olan arabacı veya küfeciye 600 kuruş pahalılık zammı ve 360 kuruş ekmek bedeli ile beraber toplam 1360 kuruş verilmesi gerekirken, 400 kuruş maaş ve 400 kuruş pahalılık zammı olmak üzere yalnız 800 kuruş verilmiştir. Bunun, bütçedeki pahalılık zammı tahsisatını idare ettirmek için reis tarafından alınmış bir önlem olduğu kâtip tarafından beyan edilmiştir.

Hâlbuki geçici memurların da pahalılık zammından hakkıyla yararlanması gerekmektedir. Kendileri bu şekilde görev yapmayı kabul etmiş olsalar bile mahkemeye müracaat ettikleri takdirde noksan verilen pahalılık zamlarıyla hiç verilmeyen ekmek bedelini almaya hak kazanacaklardır. Bunların çoğunun bir iki ay çalışmayla geçinemedikleri ve bu yüzden istifa etmekte oldukları görüldüğ̈̈nden söz konusu pahalılık zammı için bütçeye konulan 280 bin küsur kuruş tahsisattan arabacı ve küfecilere de kanunen hak ettikleri pahalılık zammının tamamının verilmesi gerekirdi. Hesaplamalar sonucu sene sonuna kadar söz konusu tahsisatın idare etmeyeceği anlaşıldığında noksanı hakkında ek tahsisat veya sarf edilmeyecek olan bütçedeki diğer tahsisattan harcanması için hükümetten izin istenilmesi gerekirdi. Bu yön düşünülmediği ve kanuna aykırı eksik sarfiyatta bulunulduğu için arabacı ve küfecilerin görevlerini terk etmesine ve yerlerine tayin olunanların da hakkıyla görevlerini yerine getirememesine sebebiyet verildiği anlaşılmıştır.

19 Mayıs 1919 tarihinden 5 Haziran 1919 tarihine kadar çarşının bazı mahallerinde tamir ve inşa edilen kaldırımların tamir ve inşasında istihdam edilen 20 usta ve ameleye 5 Haziran 1919 tarihli senet gereğince 10100 kuruş yevmiye verilmiş ise de senette belediye çavuşlarından hiç birisinin tasdiki olmadığından, söz konusu senedin kavl-i mücerredi (delilsiz, ispatsız, şahitsiz) bir şekilde kâtip tarafından tanzim edildiği, heyetin de kabul ederek sarfını tasdik ettiği görülmüştür.

\section{d. Belediye Müstahdemlerinden Bazısına Yaptırılan Elbise Bedelleri}

Bütçede tahsisatı olmadığı halde belediye müfettişi, baş çavuş, çavuşlar ve kâtip için yaptırılan elbise bedelleri olarak geçici harcama suretiyle 28 Temmuz 1919 tarihinde 16915 kuruş sarf edilmiştir. Sarftan sonra belediye meclisince ilgili personelin maaşlarından her ay beşer yüz kuruş kesilerek sene sonuna kadar söz konusu meblağın kapatılmasına karar verilmişse de aradan 4 ay geçtiği halde sadece bir aylık maaşlarından kesinti yapılmıştır. 


\section{e. Kayıt Haricinde Yapılan Muamele}

Kasapların hayvan kesmemeleri nedeniyle 1918 senesi Nisan ayı zarfında belediyece beheri üçer yüz kuruştan 46 adet taze kuzu satın alınarak 38 adedi salhanede üç kasaba 580 kuruş ücretle ayın 23, 24, 25 ve 26. günlerinde kestirilerek ahaliye satılmıştır. Tamamının satın alma bedeli ve verilen kasap ücretinden satılanlarının bedeline bakıldığında bakiyesi olarak 1982,5 kuruş fiyatıyla en iyi altı kuzunun önceki Mutasarrıf Hilmi Bey ile Belediye Reisi Ragıp Bey'in olduğu ve bu 1982,5 kuruş yevmiyenin açığı bulunduğu ambar ithalat ve ihracat defterinin birinci sayfasındaki kaydından anlaşılmıştır. Satın alma ve satış bedelleri yevmiye defterine kaydedilmeden bu muamelenin açıktan yapılması ve kestirilen 38 kuzudan 500 kuruşa yakın bir temettu' hâsıl olmuş iken kestirilenlerin değerinden daha fazla tutacağı şüphesiz bulunan en iyi altı kuzunun bedelinin o miktar eksik tutulmak suretiyle tekabül ettirilmesi sorumluluk gerektirir.

f. Çayır Hâsılatından Meclis Kararına Dayalı Olmayarak Muhtelif Fiyatlarla Satılan Buğday ve Ak Darı

1918 senesinde ortakçılar vasıtasıyla çayıra ektirilen buğday mahsulünden belediye hissesine isabet eden 1733 şinik buğdayın (2 şiniki bir ölçek itibarılla 866 buçuk ölçek kabul edilerek) 724 buçuk ölçeği 7323 kıyye 300 dirhem olmak üzere birçok kişiye çeşitli fiyatlarla satılmıştır. Bununla ilgili tutulan adi el defterinde hiç birinin satış tarihleri gösterilmeyerek içlerinden muhtelif tarihlerde bedelleri tahsil edilmiş olanların hizasına yevmiye defterinde tesadüf edilen sıra numarasının işaret edildiği ancak hizalarındaki tahsil tarihiyle yevmiye numarasının açı olduğu görülmüştür. Muğlalı Eğri Oğlu Mustafa'ya kıyyesi 18 kuruşa satılan 104 buçuk kıyye buğdayın bedeli olan 1881 ve belediye azasından İsmail Efendi'ye kıyyesi 17 kuruşa satılan 100 kıyye buğday bedeli olan 700 kuruş ve fiyatları da gösterilmemiştir.

Belediye Çavuşu Kerim Ağa'ya satılan 25, Belediye Eczacısı Osman Bey'e satılan 150, önceki Özel Muhasebe Müdürü Nuri Efendi'ye satılan 74, Düğerekli Hacı Cafer'e satılan 123, Belediye Reisi Ragıp Bey'in 3 defada aldığı 173 kıyye buğday ile başkanın hizmetçilerine verdirdiği 72 ölçek akdarı bedelinin bakaya bulunduğu görülmüştür. Böylece 1918 senesi çayır hâsılatı olarak ambar defterine kaydedilmiş olan 1235 buçuk ölçek akdarıdan beher kilesi 160'ar kuruştan 4 şahsa satılan 32 ve müteferrik şekilde 37 buçuk ölçeği 100'er ve 615 buçuk ölçeği 75'er kuruşa satılan toplam 653 ölçek darının belirlenmiş fiyatla ve fiyatı gösterilmeyenlerin kaç kuruş fiyatla satılacağına dair meclis kararı olmadığı anlaşılmaktadır.

Tamamı resmi varidat defterine veya ambar defterine kaydedilerek satışları gösterilmesi gereken zahirelerden az bir kısmı ambar defterine yazılmıştır. Buğdayın, ihtiyaca uygun olmayan, üzerine mürekkep dökülmüş adi el defterine yazılması ve her iki zahirenin satışlarında meclis kararı aranmadan kendi başına yapılması ve bir kısmının tahsil edilememesi uygun değildir.

\section{g. Mühürsüz Senetle Ödemeler}

Şemseddin suyunun, mahalle ve çarşı yollarının tamirinde istihdam edilen sekiz ameleye verilen 266 kuruş hakkındaki 25 Haziran 1919 tarihli müşterek senet, 210 kuruş istihkakı olan Todori adlı şahsa mühürlettirilmemiş ve söz konusu tamiratın icrasına ve meblağın sarfına dair meclisin kararı olmadığı gibi, senet altına yazılan tasdik şerhini yalnız reis ile azadan Tahir Efendi mühürlemiştir. Belediye ebesinin 26 Mayıs 1919 tarihinde ödenen şahsi maaş senedi de ebeye mühürlettirilmemiştir. 


\section{h. Gereksiz Birleştirme ve Senet Muhteviyatına Ek Olarak Masraf Kaydolunan Pul Bedelleri}

Açık arttırma ile ziraat ambarından satın alınan zahire bedelleri olarak ambar memuru Ethem Efendi'ye verilen 22144 kuruş 30 paranın senedine yapıştırılan 17 kuruşluk pul ve söz konusu ambardan satın alınan yarım kilo barut bedeli olarak verilen 55 kuruşun senedine yapıştırılan 2 kuruş 10 paralık pul, senet muhteviyatına ilave olarak gider kaydedilmiştir. Daireler arasında teati olunan evrak ve senetler kanunen pula tabi olmadığından ve pulların sandıktan sarfı uygun olmadığından söz konusu pul bedeli olan 19 kuruş 10 paranın tazminat olarak gelir kaydedilmesi gereklidir.

\section{Doğrudan Doğruya Sahiplerine Verilmesi Gerekirken Belediye Eczacısına Verilen Tibbi İlaç Bedelleriyle Nakliye Ücreti}

Muğla' da ikamet eden Aydınlı Fuat Bey'den satın alınan tıbbi ilacın bedeli olan 7200 kuruş, Aydın'dan getirilen tıbbi ilacın nakliye ücreti olan 500 küsür kuruş, Doktor Halil Rifat Bey'den satın alınan kulak-boğaz aletlerinin bedeli olan 1000 kuruş ve diğer malzeme bedelini de içine alan toplam 26561 kuruş on paralık 20 Ağustos 1919 tarihli senede 17 kuruşluk pul yapıştırılarak eczacıya verilmiştir. Aydınlı Fuat ve Doktor Rifat beylere ait meblağla deveci ücretinin eczacı tarafından başkanlığa yazılacak müzekkere üzerine doğrudan doğruya kendilerine verilmesi gerekirken eczacı vasıtasıyla verilmesi usulsüzdür. Böylece Belediye Başkanı Ragıp Bey'in eniştesi Dersaadetli Baha Bahir'den satın alınan beher kıyyesi 300 kuruştan 28 kıyye alkol ve 20'şer kuruştan 35 adet boş şişe bedeli olarak 14 Mayıs 1919 tarihli senet gereğince usule aykırı olarak Eczacı Osman Bey'e 8800 kuruş verilmiştir. Söz konusu alkol ve şişelerin satın alınmasına dair meclisin kararı olmadığı gibi senet altına yazılan tasdik şerhi de sadece başkan ile azadan İsmail Hakkı Efendi tarafından mühürlenmiştir.

\section{j. Bütçe Haricinde Sarfiyat}

Reis, sandık emini, kâtip, müfettiş, kalfa ve çavuşlara Temmuzdan beri ekmek bedelinin pahalılık zammı tahsisatından verilmekte olduğu görülmüş̧ür. Söz konusu tahsisatın yalnız ilgililere sarf edilmesi veyahut ekmek bedelinin de bu tahsisattan verilmesi için hükümetten izin alınması gerekirken belediye meclisinin kararına bile gerek duyulmadan sarfiyatta bulunulmaktadır. Numune fırınının 1918 senesi kânunuevvel, kânunusani ve şubat icarları olan 240 kuruş, bütçeye konulmuş 1919 senesi icar tahsisatından olarak 17 Haziran 1919 tarihinde ödenmiştir. 1919 senesi icar tahsisatı ise sadece söz konusu fırına ait olduğuna göre 1918 senesinden kalan icar bedelinin bu tahsisattan verilmesi uygun değildir ve bütçe haricinde verilmiş demektir.

Bütçedeki harcırah tahsisat1 5000 kuruştan ibaret olduğu halde Dersaadet tarafından Muğla belediye tabipliğine atanan Muhsin Bey'e, harcırahına mahsuben 21 Eylül 1919 ve 18 Kasım 1919 tarihlerinde Ziraat Bankası vasıtasıyla ücretiyle beraber 13361 kuruş 10 para gönderilmiştir ki söz konusu meblağın 8361 kuruş 10 parası tahsisattan fazladır.

Bütçeye araba hayvanları, yem, saman ve navul masrafları tahsisatı olarak 15000 kuruş konulmuş iken mevcut sandığın sayılmasında henüz masraf kaydedilmemiş olarak sandık emini tarafından nakit senetleri gösterilen 39579 buçuk kuruştan başka 6651 kuruş 10 para fazlasıyla 21651 kuruş 10 para, temizlik işleri tahsisatı için 9400 kuruş yazılı iken 667 kuruş fazlasıyla 10068 kuruş sarfiyat icra edilmiştir ki bu iki tahsisattan sarfiyat fazlası toplam 46898 kuruş 30 paraya ulaşmaktadır. 


\section{k. Meclisin Kararından Önceki Ödemeler}

Cami-i kebir Mahallesinden Giritli Mustafa zevcesi Nazife'nin verdiği pulsuz dilekçenin altına reis tarafından "bir lira itasına karar yazınız ve meblağ-ı mezburun sandıktan verilmesi kaleme" diye 26 Ağustos 1919 tarihiyle havale yapılmıştır. Nazife'ye verilen 1 liranın söz konusu tarihli senedini o günkü tarihiyle meclis tasdik etmiş ise de paranın verilmesi daha önce ve tasdiki sonradan yapılmıştır. Senedin karar defterine kaydedilmediği ve diğer sarfiyat senetlerindeki tasdiklerin de bu şekilde olduğu anlaşılmıştır.

\section{Ay Sonuna Kayıt Dışında Bulundurulmakta Olan Harp Vergisi}

Belediye reisi ile diğer tüm görevlilerin maaşlarından \%3 hesabıyla kesilen harp vergisi, kesilme esnasinda yevmiyeye makbuzat kaydedilerek ve makbuzunun doldurularak sahiplerine verilmesi lazım gelirken bir ay zarfında ve çeşitli tarihlerde kesilmiş olan meblağ usule aykırı olarak ay sonuna kadar açıkta bulundurularak ayın son günü bir aylık kesintiler kaç kuruşa ulaşır ise sandık emini tarafından bir kıta irsaliye düzenlenerek toptan gelir kaydedilmektedir.

\section{m. Masraf Senetlerindeki Eksik Muameleler}

Reis tarafından maaşlara ait senetler zamanında yazıldı̆̆ı halde tamirat, satın alma ve inşaat ücretleri senetlerinden hiç birisi vaktinde yazılmamaktadır. Bunlardan karar defterine yazılmış olanlarının altına sadece başkan imza atmakta, azalara imza attırılmamakta veya mühürlettirilmemektedir. Bu muamele usule aykırıdır.

Belediyenin altı adet sandalyesinin tamiri için marangoz Mehmet Ustaya verilen 120 kuruşun, sarf ve tamirinin gerekip gerekmediği hakkında meclisin kararı olmadıktan başka, senet altına yazılan tasdik şerhi yalnız reis ile azadan Tahir Efendi tarafından mühürlenmiştir.

\section{n. Taliplerine İhale Olunan Vergilerle Çayır Tarlalarının Müzayede Muamelelerinde Görülen Eksikler}

Damga resmi: Mezat kaimesinde müşterilerden Helvacı Süleyman'a el çektirilmemiş ve 5600 kuruşta kararlaştırılan damga resminin bu bedel ile karar verilmiş ihalesi hakkında meclisin kararı olmayıp yalnız mezat kaimesinde her iki muamelenin icra edildiği reis tarafından resmi mühürle mühürlenmiştir.

Dellaliye resmi: 12500 kuruşa karardâde (kararı verilmiş) çekildiğine ilişkin meclisçe karar verilmeyerek mezat kaimesine bu konuda yazılan şerh, belediyenin resmi mührüyle mühürlüdür.

Salhane resmi: 800 kuruşa ihale edilmiş olan işbu salhane resmi karardâde keşide olunmaksızın ihale edilmiştir

Sergi resmi: Müşterilerden Halil Baba oğlu Süleyman Efendi'ye el çektirilmediği gibi 17050 kuruş bedel ile 1 Mart 1919 tarihinde karardâdesi çekilmiş ve 3 Mart 1919 tarihinde 17361 kuruşa ihale edilmiş olan bu resmin karardâde muamelesi hakkında meclisin karar ve tasdiki bulunmamaktadır.

Kantar resmi: Müşterilerden üç kişiye el çektirilmemiş olmakla beraber 1 Mart 1919 tarihinde 20050 kuruş bedel ile karardâdesi çekilmiş ve 3 Mart 1919 tarihinde 27000 kuruşa ihale olunan mezkûr resmin karardâdesi hakkında meclisin karar ve tasdiki yoktur.

Araba yeri resmi: 10010 kuruş bedel ile 16 Mart 1919 tarihinde karardâdesi çekilmiş ve 19 Mart 1919 tarihinde ihalesi yapılmış olan bu resmin söz konusu bedellerle karardâdesinin çekilmesine 
ve ihalesinin icrasına dair meclisin kararı olmayıp bu konuda mezat kaimesine yazılan şerhler yalnız resmi mühürle mühürlüdür.

Kile ve bac-ı bazar resimleri: 3 Mart 1919 tarihinde 1192 kuruş bedelle ihale olunan kile resmiyle, 1192 buçuk kuruş bedelle ihale edilen bac-1 bazar resminin karardâdelerinin çekilmesinde meclisin kararı eklenmemiş ve yalnız resmi mühürle mühürlenmiştir.

Saburhane meokiindeki 3 bab dükkân, Kasaphane'deki 5 dükkândan dördü, Çarşı Hamamı bitişiğindeki dükkân: Bu dükkânların karardadeleri meclis kararıla yapılmamış, bu konuda mezat kaimelerine yazılan şerhler sadece resmi mühürle mühürlenmiştir.

Çayır tarlaları: 35 parçasının karardadesi meclis kararıyla çekilmeyip bu konuda yazılan şerhler yalnız resmi mühürle mühürlüdür. İadeleri hakkındaki şerhlerin altına heyetin imzaları yazılmış ise de hiç birinin mühür ve imzası yoktur. 18 parçası meclis kararıyla karardadeleri çekilmişse de ihalelerine dair olan şerhlerin altları, imzaları konulan heyet tarafından mühürlenmemiştir. Söz konusu tarlalardan 10 parçasının adi mezat kaimesine matbu kaimelerden aldırılıp yapıştııılmamış ve bu tarlalarla diğerlerinin ihale muamelesi usule aykırı olarak adi kaimeler üzerine yapılmıştır. Yukarıda yazılı gelirlerle tarlaların mezat kaimelerindeki eksiklerden başka usulen müstahdem ve müstecirlerin hiç birinden borç senedi, icar ve isticar mukavelenamesi alınmamıştır.

Mutasarrıflık müfettişi tarafından belediyenin hesaplarında yapılan incelemeler sonucunda sandık mevcudu olarak görünen miktarın 140539 kuruş 10 para, kasa nakit mevcudunun, 1250 kuruşu Osmanlı altını, 11000 kuruşu evrak-ı nakdiye ve 154 kuruş 10 parası da Hicaz pulu olmak üzere toplam 12404 kuruş olduğu anlaşılmıştır (BOA, DH.UMVM, Dos.1, no. 92, Lef.2).

\section{BELEDIYYE BAŞKANI MEHMET RAGIP BEY'IN SAVUNMASI}

Başkan Mehmet Ragıp Bey, mülkiye müfettişinin iddia ve suçlamalarına karşıllık bir savunma hazırlamış ve 12 Şubat 1920 tarihinde mutasarrıflığa sunmuştur. Her bir iddia ve suçlamanın gerekçeleriyle cevaplandırıldığı savunma şu şekildedir (BOA, DH.UMVM, Dos.92, no.8).

Fazla Sarfiyat iddia ve suçlamasına cevap

İtalya Bahriye kumandanıyla diğer siyasi kişilerin Muğla'ya geleceklerinin mutasarrıflık makamından bildirilmesi üzerine en az on kişiden olması ve bir-iki gün kalmaları muhtemel olan bu misafirler için gerekli yiyeceklerin hazırlanması, çağrıldığım mutasarrıflık makamı dairesinde Sabık Mutasarrıf Hilmi Bey tarafından resmi olarak emir buyrulmuştur. Bu emre istinaden söz konusu satın alımlar 10097 kuruşu bulmuş ve gerekli yiyecekler teşriflerinden önce hazırlanmıştır. Gelen misafirin 4 kişiden ibaret olduğu anlaşılmış ise de burada iki gece kalarak sabah kahvaltısı dâhil olduğu halde günlük 3 yemek verilmiştir. Gerektiğinde ve duruma göre resmi şekilde belediyenin sihhiye dairesinde verilen ziyafete, hükümet erkânından, askeri amirlerden, sıhhiye memurlarından ve daha bazı kimselerden de katılanlar olmuştur. İtalyan misafirlerin Muğla'dan ayrılışı esnasında da dönüş yolculuklarında yemeleri için yiyecekler hazırlanarak kendilerine verilmiş, memleket adına gerekli resmi saygı gösterilmiştir. Bu nedenle söz konusu satın alımlardan kendi evime zerre kadar bir şey alıkonulmadığı gibi esasen bu gibi insanı küçülten davranışlara da tenezzül edenlerden değilim. Bilakis satın alımlarda yetersizliği anlaşılan bazı yiyecekler evimden ilave edilmiştir.

Satın alımda bulunanlardan ayrı ayrı senet alınması meselesine gelince, belediye müfettişi güvene layık, iffet ve namus sahibi olmakla beraber bu gibi yiyecek ve içeceklerle ilgili maddeler ayrı ayrı ve aynı zamanda çarşı pazar, bir kısmı da özel surette evlerden tedarik ettirilmiş, bu nedenle bir kısmı için senet almak mümkün olmuş ise de diğerleri için mümkün olamadığından 
söz konusu masrafların gerçeğe uygun olduğu belediye meclisince kanaat hâsıl olmuş ve bu şekilde müfettişten senet alınarak sarf muamelesi yapılmıştır. “Bir şeyden maksat ne ise hüküm ona göre sadır olur" kanuni kaidesine bakılarak muamele ve cereyan etmiş ise de bu şekilde su-i muamele ve önemli kusur oluşturmaz zannederim.

\section{Fazla alınan sigara iddiasina cevap}

Ramazan Bayramı, padişahın tahta çıkışı ve milli bayram gibi resmi ve dini günlerde resmi kutlama için belediyeyi teşrif edenler sadece memur reisleri olmayıp tüm memurlar, kâtipler ve belde halkının büyük bir kısmından oluşmaktadır. Söz konusu sigaranın bir kısmı söz konusu günlerde önceden olduğu gibi mutasarrıflık dairesine verilmiştir.

Sigaraların, manifaturacı Salih Efendi'den alınmaması gerektiği söz konusu edilmekte ise de ticaret her şeyle ilgilidir. Salih Efendi'nin manifatura tüccarı olması sigara satmamasını gerektirmez. Hatta o sıralarda Muğla Reji Dairesinde sigara bulunmadığından Salih Efendi sigaraları İzmir'den getirmişti. Bu da heyetin onayı ile yapıldığı için söz konusu etmeye bile gereği yoktur.

\section{Usulsüz sarfiyat iddiasina cevap}

Nasihat Heyetinin teşriflerinden önce özel komisyon tarafından düzenlenen program gereğince hazırlanacak ziyafet malzemesinin satın alınması için Liva encümen üyelerinden Ethem, Belediye Sandık Emini Yusuf Ziya ve Belediye Müfettişi Mehmet Efendi görevlendirilmişlerdir. Komisyon ve heyetin nezareti altında gereken ve ayrıntıları özel defterde yazılı malzemenin bedeli peşin olarak ödenmek üzere satın alınmış, satın alım miktarı olan 27,186 kuruş 30 para harcamayı gösteren pullu ve tasdikli senet verilmiş, belediye heyeti tarafından da tasdik edilmiştir. Bu konuda başka işleme gerek kalmadığından bunun eksik muamele kabul edilmesi de uygun değildir.

\section{Eksik Ödemeler ve Muameleler iddiasına cevap}

Bütçeye konulmuş pahalılık zammı ödeneğinin sene sonuna kadar idare edilmesi suretiyle sarf edilmesi belediye cemiyeti tarafından şahsıma verilmiş yetkilerdendir. Küfeci ve arabacı gibi hizmetlerde geçici olarak çalışanlara bir misli maaş ve bir misli pahalılık zammı verilmesi konusuna gelince;

İdari işler için istihdam edilmiş bir arabacı veya küfecinin tayini sırasında sonradan herhangi bir itiraz ve iddiasına gerek kalmaksızın verilecek maaş ve zam miktarı kendilerine anlatılarak işe başlattırılmışlar ve hizmet ettirilmişlerdir. Bu nedenle bu husus hesap inceleme heyetinin yetkisi dışında olup başka açıklama yapılmasına gerek görmüyorum.

\section{Belediye Görevlilerinden Bazllarına Yaptırlan Elbise Bedelleriyle ilgili iddiaya cevap}

Belediye görevlilerinin yoksul durumda olmalarının yanı sıra müfettiş ve çavuşların giydiği elbiseler resmi elbise olmadığından ve üzerlerinde alametleri bulunmadığından görev esnasında esnaf ve halk tarafından tanınmamaktadır. Resmi kıyafetle görev yapabilmeleri için kâtip de dâhil olmak üzere ricada bulunmaları üzerine birer kat elbise imal ettirilmiş ve bedeli de sene sonuna kadar maaşlarından kesilmek suretiyle geçici harcama usulüyle sarfiyatta bulunulmuştur. Her birinin maaşından 500'er kuruş olmak üzere iki defada 1000 kuruş kesilmiştir. Her ay maaşlarından 500'er kuruş kesilmesine ilişkin meclis kararında bir açılık ve kayıt olmadığından ve yılsonuna kadar kesilmesi şartı bulunduğundan karar gereğince tamamının yılsonuna kadar kesilmesi tabii bulunmuştur.

Tasdiksiz ödeme iddiasına cevap 
Kaldırım işleri, belediyenin müfettiş, kalfa ve çavuşlarının nezareti altında ifa ettirilmiştir. Her ne kadar senet altına çavuşlardan hiçbirine tasdik ettirilmediği ifade ediliyorsa da belediye heyeti delilsiz işlem yapan bir heyet olmayıp tümü tecrübe sahibi, işinin ehli ve yıllardan beri belediyenin işleriyle meşgul olan kişilerdendir. Bu nedenle gereği gibi inceleme ve araştırma yapmaksızın tasdik işlemi yapmayacakları açık ve şüphesizdir. Söz konusu yevmiye ücretlerinde isimleri bulunan usta ve ameleler kaldırım inşaat ve tamirat işlerini yaptıktan sonra istihkakı hak etmekte ve kararlar tasdik edildikten sonra ödeme yapılmaktadır. Her gün kontrolleri bizzat yapmış olmam nedeniyle artık çavuşların tasdikine gerek kalmaz zannederim.

Kayıt haricinde yapılan muameleye ilişkin iddiaya cevap

Halka ucuz fiyata et yedirmek ve halkı kasapların vurgunculuğundan kurtarmak amacıyla o sıralarda belediye sandığında yeter miktarda meblağın da bulunmaması nedeniyle söz konusu kuzular tarafımdan satın alınmış ve mâl olduğu fiyatla satılarak belediye muamelelerine sirayet ettirilmemiştir. Tetkik heyetinin eleştirdiği gibi tutulan defterler belediyenin resmi ithalat ve ihracat defteri olmayıp önceki kâtip tarafından tutulan hususi bir el defteridir. Bu durum az bir dikkat ve araştırma ile anlaşılabilecek iken belediye reisi ile mutasarrıfın en iyilerinden üçer kuzu aldığını ileri sürmenin kişisel kinden kaynaklanmış olduğuna hiç şüphe bırakmıyor. Çünkü cümlenin bildiği gibi ne bir mutasarrıf ve ne de bir belediye reisi bu gibi kötü bir huya tenezzül eder. Bu şekilde şahsi ve memurluk haysiyetini feda eder takımından değildirler. Nitekim bundan on beş yirmi gün önce aynı amaçla mutasarrıflık makamından verilen bir emirle cebimden 580 küsur lira harcanarak hayvan satın aldırılıp memlekette kestirilmektedir. Bu gibi kötü menfaat peşinde koşacak bir kişinin gösterişsiz parasını belediye ve halk yararına sarf edip ve aylarca parasını belediye menfaatine hasretmeyeceği hususlarını (hala para alınmamıştır) vicdan ve iz'an sahibinin düşünmeden kabul edebileceği fikrindeyim.

1918 senesinde hâsıl olan akdarı ve buğday hâsılatının meclis kararına dayanmayarak çeşitli fiyatlarla satıldığı ve bir kısmının tahsil edilemediği iddiasına cevap

Söz konusu zahire, meclisin kararıyla çeşitli fiyatlardan çarşı ve pazarda belde rayicine uygun olarak çiftçilere ve ihtiyaç sahiplerine satılmıştır. Bedeli henüz bakayada kalanların da kaydı silinmeyerek elde tutulmuştur. Gecikme ise henüz ehil ve muktedir bir tahsildar bulunamamasından kaynaklanmıştır. Yeni kâtip, kayıt ve yazım işlemlerinin düzenli bir şekilde tutulması için çaba göstermektedir. Bununla beraber her resmi dairede olduğu gibi belediye dairelerinin de kişilerde alacağının olması tabiidir. Şunu arz ve ilave ederim ki o zaman çok yüksek olan zahire fiyatları tüm emtia ve eşya üzerinde etkisini gösterdiğinden fiyatların yüksekliği halkı geçim sıkıntısına düşürmüştür. Bilhassa fiyatlarda bir değişim sağlayabilmek ve çarşı piyasasını korumak amacıyla çeşitli zamanlarda çeşitli fiyatlarla çarşıda açıkça satış yapılmıştır ki bu girişim derhal etkisini göstererek fiyatlardaki yükseklik hemen pek fazla düşmüş, bu nedenle belediye tüm halkın takdirini kazanmıştır.

\section{Mühürsüz senetle ödemeler iddiasina cevap}

Suyollarının tamirinde kalfa ve belediye müfettişinin nezareti altında çalışan sekiz amelenin hak kazandıkları yevmiye ücreti olan 2660 kuruşun tamamının kendilerine ödendiği incelemeden anlaşılmıştır. İçlerinden 240 kuruş ücreti olan Todori'nin senedinin mühürlettirilmemesinin nedeni mührünün bulunmaması ve yazı bilmemesidir. Senet altının tasdik şerhine gelince; $\mathrm{O}$ tarihte idare heyetinin kısmen Karabağlar'da yazlıklarında bulunması ve amelenin istihkaklarının geç ödenmesi fakir olmaları nedeniyle aç kalmalarına neden olacağından idare başkanı ile azadan Tahir Efendi'nin tasdikleri yeterli görülerek ödemeleri yapılmıştır. Gerçek açık olduğundan kötü muameleye ilişkin herhangi bir şey bulunmamaktadır. 
Ebenin senedinin altında maaşını aldığına ilişkin mühür olduğu halde pulun üzerinde olmaması yolsuzluk olduğu anlamına gelmemekte olup bu da tamamlattırılmıştır.

Ziraat ambarından satın alınan zahire ile yarım kilo barut bedeli olarak verilen meblağın senetlerine yapıştırlan pul ve senet muhteviyatına ilave edilmiş olan 19 kuruş 10 paranın zarar olarak gelir kaydedilmesi gerektiği iddiasina cevap

Belediye dairesinin çekmiş olduğu tüm telgraflarla mektuplar ücrete tabi olduğu gibi belediyenin numune fırını için tarh olunan temettuun kaldırılmasına ilişkin mutasarrıflığa takdim olunan müzekkereye 3 kuruşluk Hicaz pulu ve maktu' pul yapıştırılmıştır. Belediye dairesine ait evrakın daireler arasında teati edilen evrak ile kıyaslanmaması gerekir. Söz konusu senetlere pul yapıştııılması da bu amaçla yapılmıştır. Belediye dairelerine ait evrakın puldan istisnası hakkında bir karar varsa dairemize de tebliğ buyrulması.

\section{İlaç bedelleri ve tasdik süreciyle ilgili iddialara cevap}

Söz konusu senetlerin muhteviyatını oluşturan tıbbi ilaç, alkol ve şişe bedelleriyle nakliye ücreti faturaya dayalı olup satın alma bedellerinin ödeme ve sarf şekli belediye heyetinin bilgisi dâhilindedir. Senetlerin altındaki tasdik heyetin kararı demektir. Eczaneye ait olan satın almalar öteden beri doğrudan doğruya eczacı tarafından yapılmakta olup faturası iliştirildikten sonra senedin istihkak sahipleri veya eczacı tarafından düzenlenmesinde herhangi bir sakınca bulunmamaktadır. Bunun yanında bayiler buradadır. Kendilerinden birer senet alınmak suretiyle işlemin tamamlanması mümkündür. Hatta bu işte suiistimal vukuuna zerre kadar şüphe duyulursa bayilerden tahkikat yapılması da pek mümkündür. Bilhassa söz konusu ilaçlar kullanma zorunluluğu gereği yokluğumda vekilim tarafından satın alınmıştır. Keza, ispirtoların satın alınması da bu şekilde yine eczacı tarafından icra edilmiştir. İlaçların, alkolün, şişelerin mevcudu, satış, sarf ve kayıt işlemleri eczanede mevcuttur. Senetlerin altındaki tasdikin aza heyetinin tamamının mühründen sonra kabul edilmesi sandık eminine ait iken eksiklik önceki sandık emininin bu işi geciktirmesinden kaynaklanmıştır. Sonuç itibarıyla bu da önemli olmayıp söz konusu harcamalar her ay sonunda heyetin mührü, tasdiki ve incelemesi altındadır.

\section{Bütçe dışında sarfiyat iddiasına cevap}

Pahalılık zammı ve ekmek bedelleri, genel bütçeden maaş alan memurlar hakkındaki tebligata uygun olarak aynı fasıl ve madde dâhilinde ödenmekte olduğu halde hesapları inceleme heyetinin bu konuyla ilgili eleştirilerinin bilgisizlikten ileri geldiği kanaatini oluşturmuştur. Numune fırınının 1918 senesinden içeride kalan iki aylık icar bedeli bu yılın bütçesinden değil geçen seneden devredilen mevcut sandıktan verilmiştir. Bilindiği gibi belediye bütçelerine önceki borçlar adıyla tahsisat konulup yılbaşına devredilen mevcutlar karşılık tutulmaktadır. Belediye bütçeleri genel bütçeyle kıyaslanamaz.

Belediye tabipliğine atanan Muhsin Bey'e gönderilen meblağ konusuna gelince; Muhsin Bey'in isteği üzerine ilk etapta geçici harcamalar hesabına masraf kaydedilmek suretiyle 5000 kuruş gönderilmişti. Daha sonra Karahisar'dan çektiği telgrafta harcırahının yetersizliğinden söz ederek 8000 kuruş daha istekte bulunmuştur. Bütçede karşılığ1 olmasa da Muhsin Bey'in uzun müddet yollarda kalmaması ve gönderilecek paranın bütçeye masraf kaydedileceği ve sonradan gerçek harcırahı hesaplandığında mahsup işlemi yapılacağı düşüncesiyle idare meclisinden ek tahsisat alınacağı da dikkate alınarak ödeme yapılmıştır. Muhsin Bey Dinar tabipliğine atanınca paranın bir kısmı iade edilmiş, kalan diğer kısmının da geri ödenmesi için Dinar Kaymakamlığı'na yazı gönderilmiştir. Bunun tahsili halinde geçici harcama hesapları kapattırılacaktır. Şu halde bütçedeki tahsisatı aşmak gibi bir yolsuzluk mevcut değildir. 
Temizlik işlerine gelince; içinde bulunduğumuz yılın bütçesine konulan tahsisatın yetersizliği nedeniyle sonradan Liva İdare Meclisi'nden ek tahsisat alınarak işlem tamamlanmıştır.

Meclisin kararnndan önceki ödemelerle ilgili iddiaya cevap

Reis tarafından " 1 lira verilmesine karar yazınız ve söz konusu meblağın sandıktan verilmesi kaleme" denilmesi, paranın meclis kararından önce verildiğine delalet etmez. Çok iyi hatırlıyorum ki heyetin hazır bulunduğu bir zamanda izinleri alınarak böyle bir karar yazılmasını kâtibe emir verdim. Hesap inceleme heyetinin bu indî ve keyfi sonuçlarını tuhaf karşıladım. Ne bu muamelede ve ne de diğer senetlerde usule aykırı bir işlem vardır.

Ay sonuna kadar kayıt dışında tutulmakta olan harp vergisiyle ilgili iddiaya cevap

Harp vergileri hakkında önceden beri bu şekilde işlem yapıla gelmekte ise de, sonradan işlemlerin düzene girmesi için kesintilerin kesme esnasında yevmiyeye gelir kaydedilmesi gerektiği sandık emanetine tembih edilmiştir.

Masraf senetlerindeki eksik işlemlerle ilgili iddiaya cevap

Bütçede tahsisatı mevcut olan maaşların verilmesi sırasında esasen meclis kararına gerek yoktur. Masraf kısmındaki eksik muamele ise yayla zamanı olması nedeniyle genel heyetin mevcut olmamasindan ileri gelen bir durumdur.

İsteklilerine ihale olunan rüsumat ile çayır tarlalarının müzayede muamelelerinde görülen eksikliklerle ilgili iddiaya cevap

Gerek rüsumat, çayır, arazi icar müzayedeleri karardadesi ve gerek ihale işlemleri tümüyle heyetin önünde yapılmıştır. Karardade ve ihale esnasında el çektirilmemiş olan talipler için her ne kadar münadi vasıtasıyla "ihale olunuyor" diye çarşı ve pazarda ses ve ilan ettirilmiş ise de el çektirilmeyen talipler başvuruda bulunmamış olduklarından zamdan vazgeçmiş sayılarak diğer istekliler üzerine ihale işlemi icra edilmiştir. Söz konusu işlem yukarıda ifade edildiği gibi meclis heyeti huzurunda yapılmış, sadece karardade ve ihale şerhleri eskiden beri meclis mührüyle mühürlenmekte olduğundan şahıs mührüyle mühürlendiğine ilişkin mesbuk bir muamele değildir. O sıralarda eski kâtibin istifasıyla yerine diğerinin tayinine kadar sandık emininin görev yapması ve onun da işlerinin yoğunluğu ve yazıcılıktaki acemiliği nedeniyle mültezimlerden Hicaz varakası aldırılmamış ise de sonradan alınarak işlemi tamamlanmıştır.

\section{MÜLKIYYE MÜFETTISŞININ, MEHMET RAGIP BEY'İN SAVUNMASIYLA İLGILII GÖRÜŞ VE DÜŞÜNCELERİ}

\section{a. İtalya Kumandanlarına Verilen Ziyafet}

Gelmeleri tahmin edilen on misafir için hazırlanmış olan yiyecek ve içeceklerin dört misafir geldiği halde tamamen sarf edilmiş olması ve bundan başka kendi hanesinden de bazı yiyeceklerin ilave edilmiş olması hakkındaki savunmalar doğru değildir. Çünkü misafirler bir akşamüstü gelip ertesi günün devriyesi sabah vakti dönmüşlerdir ki iki akşam ve bir gündüz yiyeceği ve bir sabah kahvaltısı olarak tamamında erkân-ı hükümetten saydığı kişiler bulunsa bile bu kadar yiyecek, meyve, sabun ve gazyağı sarf edilemez. Satın alınan yiyecekler vesaireyi tamamen kendi hanesine gönderdiği ve yemeklerin orada pişirildiği, belediye hademesinin de her defasında bir sofralık olması lazım gelen bu yemeklerden yalnız tabaklarda artan miktarını yemiş olmaları tabiidir (BOA, DH.UMVM, Dos.1, no.92, Lef.4).

\section{b. Ramazan Bayramı İle Onu Takip Eden Milli Bayramda Satın Alınmış Olan Sigara}

Kâtiplerle ahaliden belediyeyi ziyaret eden olmaz. Sadece kendisinin görüştüğü memurlar gelirler, hatta bunlardan bazıları bile makamında bulamazlar. Her ne kadar satın alınan 
sigaralardan bir kısmı mutasarrıf makamına verilecek ise de bu beş-on paketi geçmez. Çünkü makama ziyarete giden kâtipler oturmaz, sadece memurların reisleri oturur, onlara birer adet sigara verilir. Bu nedenle satın alındığı gösterilen iki buçuk kilo sigara hakikaten bu miktar ise her halde iki kilo kadarı aylarca içmek üzere kendisinde kalmıştır. Nitekim gelecek aydan sonra bir süre birinci nev' sigara içer (BOA, DH.UMVM, Dos.1, no.92, Lef.4).

\section{c. Nasihat Heyetine Verilen Ziyafet}

Kasadan evrak-1 müsbitesiz (ispat edici belge) az çok para çıkarmak kesinlikle yasaktır. Satın almalarla görevlendirildiği beyan edilen kişilere, yasağa aykırı olarak açıktan verilen tüm paraların harcama şekli ve yerlerini açıklayan el defterinin kabul edilmesi uygun değildir. Bu defterin, taraflarından tasdiksiz olduğu halde kabul edilmesiyle kendilerinden gerçek sarfiyatla ilgili senet alınması hiçbir şekilde uygun değildir (BOA, DH.UMVM, Dos.1, no.92, Lef.4).

\section{d. Belediye Müfettişi Veya Çavuşu Tarafından Tasdiksiz Olarak Verilen Kaldırım Masrafları}

Bu türden harcamalara ait diğer senetler belediye müfettişi veya çavuşlar tarafından tasdik edilmiştir. Bu senedin tasdiksiz muhteviyatının verilmesindeki hatasını örtmek için işlemler sırasında her günkü teftişlerde bizzat ifa ettiğini öne sürmesi tamamen yalandır. Çünkü şimdiye kadar yapılan kaldırımlar inşa edilirken bir defa olsun oradan geçmedi (BOA, DH.UMVM, Dos.1, no.92, Lef.4).

\section{e. Belediyeye Ait Para İle Satın Alınmış İken Kendi Kesesinden Verildiği İddia Olunan Kuzu Parası}

Kuzu hesabının kayıtlı olduğu defter, ifade edildiği gibi el defteri olmayıp matbu' ve belediyeye ait resmi ambar ithalat ve ihracat defteridir. Söz konusu defterde belediyeye ait daha pek çok muamele vardır. İncelenirse anlaşılır. Bu 46 kuzu kasabaya altı saat mesafede bulunan Gökova denilen köye gönderilen bir kasap ile belediye hademesinden bir iki kişi vasıtasıyla satın alınıp getirilmiş olacaktır. İddia ettiği gibi eğer kuzuların parası kendi kesesinden verilmiş olsaydı sandık emini resmi bir deftere bunun hesabını kaydetmez ve kendisiyle önceki mutasarrıf Hilmi Bey'in aldığ 6 kuzunun tutulan 1982 buçuk kuruş bedelinin kasa açığı olduğu şerhi verilmezdi. Bundan, kuzuların belediyeye ait meblağ ile satın alındığına şüphe yoksa da gerçeğin daha fazla aydınlatılması için bir de 10 Nisan 1918 tarihinden 16 Nisan 1918 tarihine kadar kasada kaç kuruş mevcut olduğu anlaşılmak üzere bu tarihlere ait yevmiye defteri incelensin. Verilen kuzu parası 14000 kuruş kadardır. Bakalım o vakit kasada bu miktar para var mı yok mu imiş (BOA, DH.UMVM, Dos.1, no.92, Lef.4).

\section{f. Meclis Kararıyla Satıldığı Ve Tahsildar Bulunamaması Nedeniyle Bakaya Bulunduğu İddia Edilen Zahireler}

Gerek ayrı ayrı çarşıda ve gerek toptan şuna buna satılan zahirelerin satın alım fiyatları hakkında meclisin hiçbir kararı olmadığı inceleme sırasında kâtip ve sandık emini tarafından ifade edilmiş idi. Kendisi umumi karara dayanmış olduğunu ileri sürse de bu konudaki kararlarla söz konusu zahire belediyenin en önemli gelirlerinden olduğu halde mektep çocuklarına mahsus el defterine yazılmıştır. Bu defterde kimlere satıldı̆̆ kayıtlı olan zahirenin her biri hakkındaki kararlar gösterilerek uygulanır ise gerçek ortaya çıkar. Bunun yanında raporda yazılı olduğu gibi kendisi tarafından alınan ve belediye eczacısı, belediye çavuşu ve Özel Muhasebe Müdürlüğüne verilen zahirelerin fiyatları el defterinde gösterilmemiş olduğundan bunlar hakkında meclisin kararı olmadığı kesindir. 
Bir de bunlarla raporda gösterilen diğer kişiler zimmetindeki zahire bedellerinin muktedir bir tahsildar olmaması nedeniyle tahsil edilemediği cevabını veren belediye başkanından, eskiden belediye tarafından hiç tahsildar tayin edilmiş midir ve kendi zimmetini de tayin olunacak tahsildar tarafından istenilmesi durumunda mı verecektir bu yönüyle de sorulsun (BOA, DH.UMVM, Dos.1, no.92, Lef.4).

g. Senetlerde Mühür ve İmzası Olmayan ve Meclis Tarafından Sarfı Kabul ve Tasdik Edilmeyen Kişilere Yapılan Ödemeler

İstihkak sahiplerinden alınacak senetlere mühür veya imza ettirilmesi zorunlu olduğundan mühür ve yazısı olmayan ameleye çarşıdan mühür aldırılması icap ederdi. Bu eksiklik sonradan tamamlanmış ise de heyetin Karabağlar'da sayfiyelerinde bulunmasından dolayı kendisiyle azadan birisinin tasdikinin yeterli görüldüğü şeklindeki ifadesi doğru değildir. Heyette diğer kişilerin her gün kasabaya gelip giden tüccarlar olduğuna bakıldığında hiçbir alıp verme ile meşgul olmayan Aza Tahir Efendi'nin bulunup da onların Karabağlar'dan gelmemiş olması ihtimali yoktur. Uygun ise senedi tasdik etmeyen azaların kimler olduğu ve ne gibi ticaret ve işle meşgul oldukları reisten araştırılsın (BOA, DH.UMVM, Dos.1, no.92, Lef.4).

h. Ziraat Ambarından Satın Alınan Zahirelerle Barut Bedeline Verilen Paraların Senedine Gereksiz Yapıştırılan Pul

Numune fırını hakkında makama verilen müzekkereye pul yapıştırıldığından, belediye dairelerine ait evrakın puldan muafiyeti hakkında bir karar olmadığı gerekçesiyle ziraat ambarından satın alınan zahire ve barut senetlerine pul yapıştırıldığı iddia edilmektedir. Dairelerin uhdesinde bulunan emval vergilerinin takdiri hakkında verilen müzekkerelere pul yapıştırılması zorunludur. Ancak daireler arasında teati olunan evrak ve senetlerin puldan muafiyeti damga kanunu hükümlerinden olduğundan söz konusu senetlere pul yapıştırılması ve bu pulların bedeli olan 19 kuruş 10 paranın bayie verdirileceği yerde senet muhteviyatına ilave olarak masraf kaydedilmesi hiçbir suretle kabul edilemez ve tazmin ettirilmesi gerekir (BOA, DH.UMVM, Dos.1, no.92, Lef.4).

\section{Tahsisatı Kalmamış Olduğu Halde Temizlik İşleri İçin Yapılan Harcamalar}

Temizlik işleri tahsisatından fazla harcandığ sonradan Liva İdare Meclisi'nden alınan ek tahsisattan mahsup edildiği ifade ediliyor. Bütçedeki tahsisat Temmuz zarfında tükendiğinden ek tahsisat için o zaman mazbata ile makama başvurulması gerekirken tetkik heyetinin inceleme tarihi olan Kasım sonuna kadar talep olunmamıştır. Tasdikli olmayan senetler karşılığında değişik tarihlerde sarf edilmiş olan söz konusu meblağdan 39 bin küsur kuruşun o tarihe kadar yevmiye kaydedilmediği ve söz konusu senetlerin nakit olarak tutulduğu görülmüştür. Her ne kadar sonradan ek tahsisat alınmış ise de tahsisat kalmadığı halde aylarca sarfiyatta bulunulması ve söz konusu sarfiyatın da meclis kararına dayandırılmadıktan başka harcanmış kaydedilmeyerek senetlerin nakit olarak tutulması usulen uygun olmadığından nedenleri tekrar açıklansın (BOA, DH.UMVM, Dos.1, no.92, Lef.4).

\section{j. Meclisin Kararından Önceki Ödemeler}

Cami-i kebir Mahallesinden Giritli Mustafa zevcesi Nazife'ye verilen 1 lira hakkında ilgilinin dilekçesinin altına 1 lira verilmesine karar yazınız diyerek kaleme konulan havalenin heyetin kararından önce olduğu inceleme heyetinin raporunda yer almaktadır. Havaleyi, heyetin hazır bulunduğu bir sırada muvafakatlerinin alınmasından sonra kâtibe emrettiğini ifade ediyor. Mademki heyet o sırada mevcut imiş niçin dilekçenin altına kararını yazdırıp ta imza ettirerek havale etmemiştir, uygun ise bu yönü de sorulsun (BOA, DH.UMVM, Dos.1, no.92, Lef.4). 


\section{k. Masraf Senetlerindeki Eksik Muameleler}

Cevabında, masraf senetlerine tarafından verile muamelesi yapılmamakta olduğu ifade edilse de raporun bu fikrasına sükût geçiliyor, nedenlerini açıklasın (BOA, DH.UMVM, Dos.1, no.92, Lef.4).

\section{Mezat Kaimelerindeki Eksikler}

Karardade ve ihale muamelelerinin tamamının heyet huzurunda yapıldığı, karardade ve ihale şerhlerinin öteden beri meclis mührüyle mühürlenmekte olduğu, şahsi mühürlerle mühürlendiğine ilişkin bir muamelenin geçmişte hiç olmadığı öne sürülüyor. Hâlbuki bu muameleler her dairece yürürlükte ve geçerli olan usul üzere ya mezat kaimeleri veyahut karar defteri üzerinden heyete imza ve mühürlettirilmek suretiyle ifa edilmektedir. Söz konusu muamelelerin karar kaimesine veya karar defterine geçirilerek orada mühür ve imzaları olmadığ halde onların görüşlerinin alınarak yapıldığı hakkındaki açıklamaları dikkate değer bulunmamaktadır. Bununla beraber bazı kaimeler üzerinde, karardade ve ihaleye ait şerhlerde heyetin mühür ve imzaları bulunduğundan kendi görüşüyle yapılmış olan tasdiksiz muamelelerin heyet ile görüşülerek yapıldığını kayıtla ispat etsin (BOA, DH.UMVM, Dos.1, no.92, Lef.4).

\section{m. İlave}

Önceki yıllara ait geçici harcama hesapları yüzeysel olarak gözden geçirildiğinde Şemseddin suyollarına konulmak üzere sipariş edilen demir boruların kendisi tarafından 45000 kuruşa alındığ1 ve henüz hesabının kesilmediği görülmüştür. Kâtipten araştırıldığında belediyenin bodrum katında biraz borunun bulunmakta olduğu söylenmiş idi. Söz konusu meblağa karşılık ne miktarda boru getirildiği ve bu boruların şu anda nerede bulunduğu araştırılsın ve bunlarla ilgili gelen evrak incelensin (BOA, DH.UMVM, Dos.1, no.92, Lef.4).

\section{BELEDIYYE SANDIK EMINIININ 12 ŞUBAT 1920 TARİHLİ RAPORU}

Soruşturma sırasında belediye sandık emininin kasa mevcudu ve harcamalarla ilgili görüşüne de başvurulmuştur. Raporda şu bilgilere yer verilmektedir (BOA, DH. UMVM, Dos.1, no.92, Lef.6).

Belediye hesaplarının tetkikiyle görevli heyet tarafından kasa içeriğinin sayılıp incelenmesiyle ilgili düzenlenip takdim olunan rapor mütalaadan geçirilmiştir. Sayım sırasında defter gereğince sandık mevcudu bulunması gereken 140539 kuruş 10 paraya karşılık mevcut görünen 12404 kuruş 10 para altın, evrak-ı nakdiye ve pul bedeli düşüldükten sonra kalan 128135 kuruş hakkındaki zorunlu nedenler şu şekilde arz olunur.

Söz konusu meblağdan söz eden raporun birinci kaleminde yazılı 190 kuruş, eczanenin tamir masraflarının kalanıdır. Söz konusu eczane 1918 yılından beri günlük 300 kuruş icarla belediyenin kiralamasında olup kiralama sırasında def'aten tamirine lüzum görülmüş, tamirat masrafları aylık icar bedelinden mahsup olunmak üzere marangoz esnafından Yorgi Oğlu Vasil Ustanın üstü müfredatlı geçici senedine binaen verilen 3040 kuruştan ay be ay belirli miktarda kesilmiştir. Söz konusu meblağ, eksik kalmış olan akçe olup bu para da 1919 yılı Ekim ayı icarının tesviyesi sırasında kesilmiş ve yerine konulmak suretiyle kapanmıştır.

İlgili raporun ikinci kaleminden başlayarak yirmi kalemini oluşturan ve tamamı 34389 buçuk kuruş olan meblağ, belediye için istihdamı zorunlu bir baş hayvan ve araba bedeli, araba tamiratı, genel mahaller için sarf olunan kireç bedeli, söz konusu hayvanların 1919 yılı Ağustos ayından beri zorunlu ihtiyaçlarından olan arpa, saman, navul, semer ve araba takımlarının tamirat bedeli gibi zorunlu oldukça sahiplerinden satın alınarak senet karşılığı verilen paradır. Ancak bütçede 
tahsisatı kalmadığından söz konusu senetler yevmiyeye dâhil edilemeyerek açıkta bırakılmakta ve bir taraftan da mutasarrıflık makamına arz olunmakta olduğu gibi 12 Ocak 1920 tarihli mazbata üzerine Liva İdare Meclisi'nden yazılan ilamla verilen 80000 kuruşluk ek tahsisattan mahsup edilerek yevmiyeye dâhil edilmiştir.

Bu arada bir 5000 kuruş vardır ki o da belediye dairesine kış nedeniyle takılması zorunlu olan camın burada ve Rodos'ta bulunamaması nedeniyle o aralık Dersaadet'e giden Hacı Çakır Zade Kemal Efendi vasıtasıyla getirilmek üzere Kayın pederi Hacı Kara Mustafa Zade Tahir Efendi'ye senetle verilen fakat satın alım miktarı bilinememesi nedeniyle açıkta tutulması zorunlu olan akçedir. Kemal Efendi uygun camı bulup getiremediğinden alınan senet iptal edilmiş, hesap incelemesinden sonra 8 Aralık 1919 tarihinde söz konusu meblağ kendisinden geri alınarak yerine konulmuştur.

13520 kuruş ise mebusan seçimleri için seçim dairelerine giden seçim memurlarının teftiş heyetinin kararıyla takdir olunan meblağdan, hak edenlerin talep ve ısrarı üzerine verilen paradır ki bu gibi masrafların belediye gelirleri müsait olan mahallerce belediye sandığından ödenmesi mebusan seçimleri kanununda açıklanmıştır. Bütçede her ne kadar tahsisatı yoksa da yılsonunda belki harcamalardan arta kalacak gelirler fazlasından, olmadığı takdirde mal sandığından ödenir düşüncesiyle seçim işinin bir an önce yapılmasının önemi göz önünde bulundurularak istihkaklarını peşin almakta ısrar edenlere ellerinden senet alınarak ödenmiştir. Bu da zaten kabul ve tasdik olunacağı tabii olan maddelerdendir.

2930 kuruş 10 para belediye reisinin, 8274 kuruş, belediyede görevli kâtip ve hademenin 1919 Kasım maaşlarına mahsuben ilgili ayın sonunda kendilerinden alınacak bordro muhteviyatındaki istihkaklarından mahsup olunmak üzere her birinden geçici ilmühaberler alınarak verilen akçelerdir. Söz konusu meblağ dahi belediye sandığının 19 Kasım 1919 tarihinde mühürlenip de hesapları inceleme heyetinin 30 Kasım 1919 tarihinde incelenmiş hesaplarından sonra düzenlenen bordro üzerinde ilgili görevlilerden kesilmiştir.

600 kuruş, belediye fırınının 1919 yılı Kasım ayı yakacak bedeli olup, söz konusu yakacaklar aybaşından sonuna kadar hafta hafta dört kez tahakkuk eden ve sonuncusu 800 kuruşu geçmemek üzere kararlaştırılmış olan meblağa mahsup Kasım başından sandığın mühürlenme tarihi olan 19. gününe kadar üç defada verilen ve hesap inceleme memurlarının tetkikiyle sandığın açılışında usule göre senet alınarak yevmiyeye dâhil edilmiş olan meblağdır.

51231 kuruş 10 paranın 50000 kuruşu, belediye yararına satın alınan 500 liralık iç borçlanma tahvillerinin bedeli, 1231 kuruş 10 parası da o sırada belediye sandığında o miktar akçenin bulunmaması nedeniyle peşin olarak alınabilen 300 liralık tahvillerin Ziraat Bankası'na rehin verilmesiyle 200 liralık daha tahvil alınması için bankaya verilen faizdir. Bu konudaki zorunluluk da şu nedenlerden kaynaklanmıştır.

O aralık devlet tarafından alınan kural ve karar üzerine sarf ve satış için çeşitli teşvikler sağlanması ve iç borçlanma tahvilleri hakkında gelmekte olan emirler nedeniyle, ileri gelen memurlardan oluşan, genel ve özel şekilde mutasarrıflık makamında toplanan meclislerde teşvik için belediyenin de borçlanmaya katılması uygun bulunmuştu. Sandığın mevcut miktarıyla alınabilecek 300 liralık tahvilin bankaya rehin gösterilerek borçlanmanın hiç olmazsa 500 liraya yükseltilmesine karar verilmiş, Ziraat Bankası memuruyla cereyan eden resmi haberleşmeyle de sabit olduğu gibi belediye adına muamele olunmuş 500 liralık tahvilatın ilk taksitinin neması olarak 1250 kuruş para da 1919 Mart tarihli yevmiyeye gelir kaydedilmiştir.

Söz konusu tahvillerin bedellerinin masraflar yevmiyesine dâhil edilmeyerek açıkta tutulması konusuna gelince, herkesin bildiği gibi masraf kaydı lazım gelen meblağ sandıktan 
çıkan ve bir daha dönüşü olmayan paralar hakkındadır. Tahviller ise tedavül eder, alınır, satılır yani Osmanlı Bankası'nın banknotu veya maliye hazinesinin nakdiye evrakı gibi aynî nakit ve aynî para bulunmasıyla sandıktan çıkan akçenin yerine konulduğunda ihracatın yerini doldurmuş ve böylece masraflardan sayılmamış olarak tanınmıştır. Böylece getirdiği nema, hesap incelemesinden 10 ay önce irat kaydedilmiş olması nedeniyle hiçbir suistimal ve yolsuzluk düşüncesini akla getiremez.

Bir kalemden oluşan 10000 kuruş da belediye için satın alınan tıbbi ilaç bedeline mahsuben ilmühaberle belediye eczacısına tavizen (ileride gelirinden kesilmek şartıyla) verilen paradır. Bunun ayrıntısı da şöyledir:

Söz konusu meblağ, eczane için görülen acil ihtiyaç ve menfaat gereği Aydın muhacirlerinden Fuat Bey'in eczanesinden o vakit belediye başkanlığı vekâletinde bulunan belediye azaları Muhsin, Molla İsmail ve Tahir Efendilerle Doktor Hüseyin ve Eczacı Osman Beyler tarafından satın alınıp götürü olarak 25500 kuruşa pazarlık edilen ilaç ve sıhhi malzeme vs. bedeli için peşinen verilmesi şart olan akçedir.

Sandığın mühürlenmesinden bir buçuk ay önce Eczacı Osman Bey'in 10 Ekim 1919 tarihli geçici ilmühaberiyle ilaç tahsisatı için idare meclisinden mazbata ile istenen ödeneğin gelmesiyle söz konusu ilaçların bedeli tamamen ödenmiş, mal sahibi Fuat Bey'den alınacak senede mahsup olunmak üzere belediye sandığından verilmiştir. Belediye sandığının mühürlenip hesaplarının incelenmesinden sonra da tahsisat talep emri idare meclisi kararıyla ulaştığında gerekli muamelesi yerine getirilerek yevmiyeye dâhil edilmiştir.

Söz konusu kalemlerin sonunda bulunan 2000 kuruş da Çayır Memuru Hüseyin Çavuş'a 10 Haziran 1919 tarihli ilmühaberle verilen paradır. Hüseyin Çavuş'a, çayırda memur iken Muğla'ya gelememesi nedeniyle zorunlu ihtiyaçları ve günlük geçimi için önceki Sandık Emini Ziya Efendi tarafından, kendisi ve bekçi arkadaşı Mehmet'e, belediyenin diğer görevlilerine aybaşına kadar zorunlu olarak verilip de sonunda bordrolarından mahsup edildiği gibi çayır işinin bitiminde muamele olunmak üzere verilmiştir. Ancak çayırın da o sıralarda işlerinin bitmesine bir şey kalmamış iken Hüseyin Çavuş başka bir göreve tayin olunmuş ve görevi bırakıp dışarıya gitmiştir.

\section{BELEDIYYE SANDIK EMİNINİN AYRINTILI RAPORUNUN ÖZETİ}

Muğla belediye sandık emini tarafından özetlenerek mutasarrıflı̆̆a sunulan rapor özetinde şu bilgilere yer verilmektedir (BOA, DH. UMVM, Dos.1, no.92, Lef.7).

Temizlik ve tamiratla ilgili 39579 kuruş 20 para, sarf edilmesi zorunlu olduğu için ödenen ve senetleri nakit olarak saklanıp, tahsisatı geldiğinde sarf işlemleri belediye meclisinin $16 \mathrm{Kasım}$ 1919 tarih ve 504 sayılı kararına dayanan bir meblağ olup sonradan tahsisatı geldiği için gerekli işlemleri yerine getirilmiştir.

13520 kuruş, mebusan seçim memurlarının ücretleri olup belediye gelirlerinin yeterli olmaması nedeniyle maliye veznesinden ödenmesi girişiminde bulunulmuş, konunun önem ve aciliyetine binaen hak sahiplerine senet karşıllğında ödenmiş ve senetleri kasada saklanmıştır.

Memur ve müstahdemlerin maaşlarına mahsuben verilen paralar, pahalılık nedeniyle maaşlarının azlığından geçim sıkıntısı içinde olduklarından destek olmak amacıyla (istihkaklarını aşmamak üzere verilmek koşuluyla) belediye heyetinin emir ve izni üzerine her birinden ilmühaber alınarak verilmiş ve maaşlarından mahsup edilmiştir. Hatta bu muamele bazı kurumlarla devlet dairelerinden sayılan muhasebe-i hususiye ve muvazene-i umumiye dâhilinde 
bulunan düyun-u umumiye dairelerinde bile mevcuttur. Çünkü olağanüstü durum devam etmektedir.

Fırın yakacak bedeli olarak aylık 800 kuruş verilmesi karar gereği olduğundan o zaman ayın yirmisine kadar 600 kuruş verilmiş, kalanı da senet alınarak resmi işlemleri tamamlanmıştır.

51231 kuruş 10 para belediye adına satın alınan iç borçlanma senetleri olup matbu' makbuzlar nakit olarak heyet huzurunda Rıza Efendi' den devralınmış ve saklanmaktadır.

10000 kuruş olan tıbbi ilaç bedeli, memleketin ihtiyacı için satın alınacak ilaçlar için ödenmek ve resmi senetle değiştirilmek üzere geçici ilmühaber alınması karşılığında ödenecek meblağdır. Reis Vekili Muhsin Efendi'nin emri ve heyetin bilgisi dâhilinde sonradan resmi senedi alınarak resmi işlemleri tamamlanmıştır.

2000 kuruş, 1919 yılında Çayır bekçisi bulunan Hüseyin Çavuş'un maaşına mahsuben diğer görevlilere olduğu gibi Ziya Efendi tarafından verilerek karşılığında geçici ilmühaber alınan ve nakit olarak heyet önünde devren teslim alınıp gerekli işlemleri derdest edilmiş meblağdır.

146 kuruş olan harp vergisine gelince, mebusan seçimi memurları için geçici olarak verilen harcırahın tahsisatı olmaması nedeniyle henüz bütçeye masraf kaydedilememesi ve senet muhteviyatının belediyeden $\mathrm{mi}$ yoksa maliye tarafından $\mathrm{mi}$ sarf edilmesi gerektiği bilinmediğinden söz konusu meblağ hangi kasadan verilir ise harp vergisinin de oraya ait olacağ muamele sonucu anlaşılacağından vergi irat kaydedilmemiştir. Gelişmelerin sonucuna göre harp vergisinin de oraya ait olacağı işlem sonucu anlaşılacağından ona göre muamele edilmesi tabiidir.

Diğer rapor defterinin 4. sayfasında yazılı olan meclis kararından önceki ödemeler konusuna gelince, ihtiyacı nedeniyle başvuruda bulunan kişinin başvurusu üzerine başkanlık makamından verilen emir gereğince tasdik şerhi yazılarak heyetin tasdikinden sonra ödenmiş ve ispat edici evrakı saklanmıştır.

Senetlerdeki eksik işlem konusu da şöyledir. Zamanındaki idari görevim döneminde maaş sahiplerinden bordro gereği kesilen tekaüt aylıklarının ve harp vergilerinin gelir kaydedildiği belgeleriyle ispatlanmış olup kayıt dışı herhangi bir şey bulunmamaktadır.

Senetlerde verile muamelesi olmadı̆̆ konusuna gelince, benden öncekilerin dönemlerinden bu yana bu şekilde işlem takibi yapılmakta olduğundan, ödemeler tüm senetlerin altı belediye heyeti tarafından tasdik edilmesinden sonra yapılmaktadır.

\section{BELEDIYYE BAŞKANI MEHMET RAGIP BEY'IN IDDIAA VE SUÇLAMALARA VERDIĞİ CEVAPLARA İLIŞKİN MUTASARRIFLIĞA SUNDUĞU 12 ŞUBAT 1920 TARİHLI RAPOR}

Belediye Başkanı Ragıp Bey, belediye dairesinin 1919 yılı hesap işlemlerinin inceleme sonuçlarıyla ilgili rapordaki maddelerin hizasına gerekli izahatta bulunduktan sonra açıklamalarının özetini ayrıca mutasarrıflık makamına da sunmuştur. Raporunda şu açiklamalara yer vermiştir (BOA, DH.UMVM, Dos.1, no.92, lef. 8).

İncelemeden, durumun anlaşılacağı gibi inceleme heyetinin görevi belediye hesaplarını incelemek ve herhangi bir suiistimal hissettiğinde gerekli delilleriyle ortaya çıkarmak olduğu halde bunca incelemeye rağmen Allah'a şükür böyle bir muamele bulamadıklarından senetler üzerindeki verile ve tasdik şerhlerini ve buna benzer söz etmeye değmez bir takım maddelerle raporlarını yazmak zorunda kaldıkları görülmüştür. Sizin de bildiğiniz gibi belediye daireleri mahalli birer kurumdan ibarettir. Bazen öyle zorunlu ve acil muamelelere maruz kalınıyor ki ne heyetin toplanmasına ve ne de uzun boylu incelemeye vakit bulunabiliyor. 
Söz konusu raporun bir fıkrasında değinilen İtalya kumandanının davet meselesi buna örnektir. Gerçi o maddedeki harcamaların oluşumu hakkında ayrıntılı açıklamada bulunulmuş ise de şahsınızı daha fazla aydınlatmak için tekrar bazı hususların açıklanmasını görev kabul ederim. Şöyle ki:

İtalyan kumandanın Muğla'ya teşriflerini haber alan önceki Mutasarrıf Hilmi Bey tarafından şahsım akşam alaturka saat on bir buçukta makama davet edilerek isimlerini hatırlayamadığım bazı kişiler mevcut olduğu halde İtalyan Bahriye kumandanının memleketimizi ziyaret amacıyla 10 kişiden oluşan maiyetiyle ertesi günü sabah Muğla'ya gelecekleri ifade edilmiş ve memleketin şeref ve haysiyetiyle uygun olmak üzere uygun mahalde iaşe ve barınmalarının sağlanması için emir verilmiştir.

Zamanın yetersizliği nedeniyle belediye heyetinin toplanıp karar almasına imkân bulunamamış olduğundan Hilmi Bey'in huzurunda düzenlenen liste gereğince gerekli yiyecek ve içeceklerin hazırlanıp satın alınması için derhal belediye müfettişine emir verilmiş ve aynı zamanda makama çağrılan kasap Abdal Oğlu Halil İbrahim'den bir de koç satın alınmıştır. Arz edildiği gibi satın alımların çoğunun evlerden ve bir kısmının da çarşıdan ayrı ayrı ve perakende suretiyle yapılmış olması nedeniyle bayilerin her birinden senet alınamamış ve alınmasının imkânı da görülememiştir. Bazı toplu satın alımlar için mesela kasap Halil İbrahim'den alınan koç bedelinin ödendiğine ilişkin senet alınması mümkün idiyse de işlemlerin eşit bir şekilde yürümesini sağlamak amacıyla heyet-i umumiye için ayrıntılı bir pusula iliştirilip mutemetlerden birer senet alınmakla yetinilmiştir.

Bu konuda herhangi bir tereddüt ve şüpheye mahal bırakmayacak şekilde söz konusu bayilerden tahkikat yapılması mümkünken inceleme heyetinin yapılan masrafları fazla ve harcamaları yolsuz kabul edip tenkide kalkışması dışarıdan gelecek olan bu gibi yabancılara karşı ne gibi fedakârlıklar gösterilmesi gerekeceği konusunda görgülerinin olmamasıyla açılanabilir. $\mathrm{Bu}$ durumu takdir edemezlerse de araştırabilirlerdi. İşte söz konusu maddeler hakkında yürüttükleri incelemenin bu türden olduğuna tam kanaat getirmem nedeniyle söz konusu etmeye gerek görmüyorum.

Ayrıntılarıyla arz ettiğim cevaptan anlaşılacağı üzere sorulan maddelerle ilgili olarak herhangi bir suiistimal ve kişisel menfaat söz konusu değildir. Sadece belediye işlerinin gecikmeden yürütülmesinin sağlanması için yapıldığı inancıyla bu cevapname düzenlenip takdim edilmiştir.

\section{MÜFETTISŞİN BAŞKAN RAGIP BEY'DEN CEVAPLAMASINI İSTEDİĞİ EK SORULAR VE CEVAPLARI}

Soruşturma sürecinde gerek başkan Ragıp Bey'in ifadelerinden gerek sandık emininin rapor ve verilerinden mülkiye müfettişinin aklına sorulması gereken yeni soruların geldiği de anlaşılmaktadır. Müfettişin değişik tarihlerde sormuş olduğu ek sorular kâğıtların üst tarafına yazılmış, Başkan Ragıp Bey'in cevapları da her bir sorunun hemen altında yer almıştır. Ek sorular da şunlardır (BOA, DH.UMVM, Dos.1, no.92, Lef.9).

Soru 1. İtalyan bahriye kumandanıyla 3 kişiden oluşan maiyetine hanenizde bir akşam yemeğinden ibaret olarak verilen ziyafet için 10097 buçuk kuruş masraf kaydedildiği anlaşılmış ve bu masraf çok fazla görülmüş olduğundan:

a. Ziyafette kimler mevcut idi?

b. Yemeklerin çeşidi

c. Malzemenin kimlerden kaçar kuruşa tedarik edildiği 


\section{d. Yemeklerin nerede pişirilip hazırlandığı}

e. Ziyafet için satın alınan malzemeden bir şey artıp artmadığı hakkında ilave olarak açıklamada bulunulması rica olunur. 28 Şubat 1920 Mülkiye Müfettişi.

Sorunun cevabı:

İtalya Bahriye kumandanının Muğla'ya teşrif edeceklerini haber alan Livamızın önceki mutasarrıfı Hilmi Beyefendi tarafından geçen Mart ayının 7. günü akşam alaturka saat 11 buçukta makama davet olundum. İsimlerini hatırlayamadığım bazı kişiler mevcut olduğu halde İtalyan Bahriye kumandanının memleketimizi ziyaret amacıyla 10 kişiden oluşan maiyetiyle ertesi günü sabah Muğla'ya gelecekleri ifade edilmiş ve memleketin şeref ve haysiyetiyle uygun olmak üzere uygun mahalde iaşe ve barınmalarının sağlanması için emir verilmiştir.

Hilmi Bey'in huzurunda düzenlenen liste gereğince gerekli yiyecek ve içeceklerin hazırlanıp satın alınması için derhal belediye müfettişine emir verilmiş ve aynı zamanda makama çağrılan Kasap Abdal Oğlu Halil İbrahim'den bir de koç satın alınmıştır. Şahsımın hanesinde resmikabulleri yapılmış ve konaklamışlardır. İlişikte sunulan pusulada yazılı satın alımlar, kişilerden, evlerden bir kısmı da çarşıdan ayrı ayrı ve perakende suretiyle yapılmış ve fiyatları hizalarında rakamla gösterilmiştir. Pişirilen yemeğin çeşidini zamanın geçmiş olması nedeniyle hatırlayamayacağımdan bir general ve memur reislerine karşı ne gibi çeşitten pişirilip verileceğinin nezdinizce takdir buyrulacağını zannederim.

Bunun yanı sıra gelen misafirin 4 kişiden ibaret olduğu anlaşılmış ise de söz konusu misafirler burada iki gece kalarak sabah kahvaltısı dâhil olduğu halde günde üç defa yemek verilmiştir. Duruma göre resmi şekilde belediyenin sıhhiye dairesinde verilen ziyafette hükümet erkânından önceki Mutasarrıf Hilmi Beyefendi, Muhasebeci Mehmet Kamil Bey, Sıhhiye Müdür Vekili Hüseyin Bey, Nizamiye Alay Kumandanı Sait Bey, jandarma Kumandanı Rifat Bey ve isimlerini hatırlayamadığım daha bazı memur reisleri beyefendiler de sonradan yemeğe katılmışlardır.

Bunlardan başka yemek dağıtımında hizmet eden önceki Orman Muamelat Memuru Hüseyin Efendi, Çekirge Mücadele Müdürü Cevat Efendi, belediye hademesi, jandarma ve askeri hademeler de geride kalan yemeği yemişlerdir. İtalyan misafirlerin Muğla'dan ayrılışlarında yolculukları sırasındaki yiyecekleri de ayrıca hazırlanarak satın alımlara dâhil olmayan ve yetmeyen, tatlı ve börekle ilgili un, nişasta ve ekmeklerden başka tavuklar da şahsımın hanesinden ilave edilerek verilmiş, memleket adına gereken resmi saygılar ifa edilmiştir.

Satın alımlardan zerre kadar şahsımın hanesinde bir şey alıkonulmadığı gibi aslında bu gibi hırslı emellere de tenezzül edenlerden değilim. Şu kadar ki belediye dairesine gönderilen ve kendi hanemde kullanılan avize büyük lambalara konulan gazyağından belki lambalarda bir şey artmış ise buna ihtimal verebilirim. Şunu da ilave edebilirim ki hanemdeki aşçıdan başka dışarıdan aşçılık eden kadınlara verilen ücretin de bu hesaptan hariç şahsi kesemden harcandığını arz eder, gerçek durumu adilane anlayışınıza takdim ederim. 29 Şubat 1920 Muğla Belediye Reisi.

Soru 2. Bu misafirlerin Muğla'da kaç gün kaldığının ve kaç defa yemek verildiğinin tahkiki. 6 Mart 1920 Mülkiye Müfettişi

Sorunun cevabı:

Bahriye Miralayı Kaptan Giovanni, maiyetinde tercümanlık görevi yapan Dr. Nakarato Caspio ile beraber bir emir neferi olduğu halde geçen Martın 8. günü öğle zamanı Muğla'ya gelerek Belediye Reisi Ragıp Bey'in hanesinde misafir edilmişlerdir. 3-4 kişilik özel hafif bir öğle yemeği yenmiş, akşam da yine reisin evinde 6 kişilik bir sofra tertip edilmiştir. Ertesi günü yine 
aynı hanede 5 kişilik bir öğle yemeği yendikten sonra akşam belediye dairesinde Mutasarrıf Hilmi Bey, Giovanni, Dr. Nakarato, Jandarma Binbaşısı Rifat, Asker Alma Şube Başkanı Saffet, Nizamiye Tabur Kumandanı Sait, Muhasebeci Kamil, Belediye Reisi Ragıp, Mutasarrıf Hilmi Bey'in oğlu Rüştü, Dr. Hüseyin Efendilerle kendisinin bulunduğu 11 kişilik bir ziyafet verilmiştir. Ertesi günü sabah bir arabaya binerek Milas'a doğru hareket etmiştir. Böylece Muğla'da bir buçuk gün kalan heyete dört defa yemek verilmiş olduğu mülkiye müfettişine arz olunur. 7 Mart 1920 Mehmet Ragip.

Soru 3. Şemseddin suyolları için demir boru getirilmek üzere 45.000 kuruş avans alındığ halde hesabının kesilmediği ifade edilmektedir, nedenleri ve ne kadar boru getirilmiş olduğunun bildirilmesi. Ayrica 10 Nisan 1919 tarihinden 16 Nisan 1919 tarihine kadar belediye kasası mevcudunun bildirilmesi. 6 Mart 1920 Mülkiye Müfettişi.

Sorunun cevabi

1916 yılı belediye bütçesinin 6. faslının 3. kısmında yazıldığı gibi Özel İdareden belediyeye Muğla suyollarının masrafları karşıllı̆ı olarak Muavenet Akçesi'nden 45000 kuruş tahsis edilmiş, özel muhasebeden çekilen bu meblağ 2 Kasım 1916 tarih ve 1187 numaralı makbuzat sütununa gelir kaydedilmiştir. Geçici harcama usulüyle suyollarının geliştirilmesinde kullanılacak olan meblağ, o sırada bazı işler nedeniyle İzmir ve Dersaadet'e gitmem gerektiğinden demir boru satın almak üzere tarafımdan alınmış ve yevmiyenin 5 Kasım 1916 tarih ve 608 numaralı masraf sütununa kaydedilmiştir. İzmir ve Dersaadet'te yaptığım araştırmalarda ihtiyacımıza uygun boru bulunamayınca satın alınıp tedarik edilememiş ve durum Dersaadet'ten Mutasarrıflığa bildirilmiştir.

Mutasarrıflıktan aldığım cevapta söz konusu para ile memleketin ihtiyacı olan şeker ve gaz satın alınması emredilmişti. Dersaadet'te Şehremanetine yapılan müracaatta gaz ve şeker kalmadığı anlaşılınca döndügümde para sandığa aynen iade edilerek yevmiyenin 15 Şubat 1916 tarih ve 1056 numaralı makbuzat sütununa geri iade kaydedilmiştir.

Açıklamalar kısmında şeker ve gaz satın alımı için sarf edilip geri iade edilen ibaresiyle kaydedildiği ve söz konusu meblağın halen hesabının kesilmediğine ilişkin zatınıza verilen bilgilerin gerçeğe aykırı ve kişisel garazdan ibaret olduğunu arz eder, ilgili meblağın kaydının incelenmesini sağlamak üzere sandık yevmiye defterini de takdim kılabilirim. 10 Nisan 1919 tarihinden 16 Nisan 1919 tarihine kadar olan sandık mevcudunu gösterir bir adet onaylı pusulanın da ekte arz edildiği bildirilir. 8 Mart 1920 Belediye Reisi Mehmet Ragıp.

Pusulada, kasa mevcudunun 10 Nisan 1919 tarihinde 227740 kuruş 30 para, 16 Nisan 1919 tarihinde de 237360 kuruş 30 para olduğu beyan edilmiştir (BOA, DH.UMVM, Dos.1, no.92, Lef.11).

Soru 4. Savunmanızın bir fıkrasında belediye sandığında yeterli miktarda para bulunmaması nedeniyle kuzuların tarafınızdan satın alındığının belediye muamelatına intikal ettirildiği ifade ediliyorsa da söz konusu tarihte belediye sandığında yeterli akçe bulunduğu ekli yevmiye münderecatından anlaşılmaktadır. Kuzu hesabının kayıtlı olduğu defter el defteri olmayıp belediyenin ambar ithalat ve ihracat defteri olduğu ve söz konusu defterde belediyeye ait daha pek çok muamelenin kayıtlı olduğu hesap inceleme heyeti tarafından ifade edilmiş olduğundan izahatta bulunulması. Mülkiye Müfettişi 9 Mart 1920.

\section{Sorunun cevabi}

Yukarıda yazılı emir değerlendirildi. Ekli pusulada belirtilen sandık mevcudu 1919 yılı Nisan ayına ait olup kuzular, 1918 yılı Nisan ayı içinde satın alınmıştır. Söz konusu kuzuların bedeli 
bizzat kesemden verilerek ve mâl olduğu fiyatıyla memleketin ihtiyacı için kestirilip sattırılmıştır. Ambar ihracat ve ithalat defteri adı verilen defter önceki kâtip tarafından hatırlatma olarak kullanılan adi bir el defteridir. Arzu buyrulur ise söz konusu defter takdim edilebilir. Konunun derinliğine araştırılmasını, bu konuda bir kötü muamele ve para kaçırmaya yönelik hiçbir yönünün olmadığını arz ederim. 10 Mart 1920 Belediye Reisi Ragıp.

Soru 5. Kuzuların satın alındığı 1918 yılı Nisanının 10 ila 16. günleri arasındaki belediye sandığı mevcudunun ve şayet sandık mevcudu müsait ise belediye hesabına mevcudunuzdan para sarfına neden gerek görülmüş olduğunun bildirilmesi. 13 Mart 1919 Mülkiye Müfettişi

Sorunun cevabi

Ekte sunulan pusula içeriğinden anlaşılacağı üzere 1918 yılı Nisanının 10'undan 16. günü dâhil olduğu halde söz konusu tarihte 58022 kuruş 15 para sandıkta mevcuttur. O sıralarda, devletçe gerektiği için satışa sunulan iç borçlanma tahvillerinden hiç olmazsa 1000 liralı̆̆ının belediye adına alınması, makamına davet eden önceki Mutasarrıf Hilmi Beyefendi tarafından emir buyrulmuşsa da sandık mevcudunun yetersizliği nedeniyle 500 liralığı için tarafımdan taahhütte bulunulmuş idi. Bu nedenle sandık mevcudundan 50000 kuruşu söz konusu taahhüde, kalan 8000 küsür kuruşunun da yevmiye masrafı vesairesine karşılık bulundurulması zorunluluğuna binaen kuzuların bedelleri tarafımdan ödenmiştir. 14 Mart 1920 Belediye Reisi Mehmet Ragip.

\section{DÂHİLIYY NEZARETI'NİN MEHMET RAGIP BEY HAKKINDAKİ AZİL} YAZISI

Başkan Mehmet Ragıp Bey'in soruşturma evrakıyla teftiş heyetinin fezlekesi Dâhiliye Nezareti tarafından da incelendikten sonra bazı hususlara açıklık getirilmesi gerektiği ortaya çıkmıştır. 1 Mayıs 1920 tarihinde Umum Vilâyât Müdüriyeti'nden Menteşe Mutasarrıflığı' na bir tahrirat gönderilerek belediye kanununun ilgili maddeleriyle, belediye muhasebe usulü talimatnamesinin özel maddeleri gereğince tüm satın alımlar ve her türlü sarfiyat için ilk önce belediye meclisinin kararının alınması, miktarı daha önceden tahmin edilemeyen satın alımlar için de bir meblağın kabul edilerek tasdikli bir bordro ile hesaplandıktan sonra diğer devlet dairelerinde olduğu gibi mutemede teslim edilmesi gerektiğine dikkat çekilmiştir (BOA, DH.UMVM, Dos. 1, no.92, Lef.13).

Nezaret tarafından 17 Eylül 1920 tarihinde Menteşe Mutasarrıflı̆̆ı'na gönderilen diğer bir tahriratta da, mülkiye müfettişinin Muğla Belediyesi'ndeki suiistimallerle ilgili tahkikat raporundan, bütçe dışında usule aykırı sarfiyatta bulunulduğu, hesap işlemlerinin usulü dairesinde tedvir edilmediği, müzayede ve ihalelerin usulüne uygun şekilde yapılmadığının anlaşıldığı bildirildikten sonra şu açıklamalarda bulunulmuştur:

Ziyafetler ve bütçe dışındaki diğer harcamalar, ita amirinin sorumluluğunu gerektiren hallerdendir. Belediye başkanları, belediyenin tüm işlemlerinde hesap işlerinin de düzgün bir şekilde döndürülüp yürütülmesine nezaret etme göreviyle yükümlü iken maaşlardan yapılan kesintilerin kayıt dışı bırakılması, belediye memurları için diktirilen elbise bedellerinin maaşlarından kesilmemesi, müzayede kaimelerinde müşterilerden bazılarına el çektirilmeden ve belediye meclisinin kararı olmadan ihale işleminin yapılması, belediye mülklerinin icarında sözleşme düzenlenmemesi belediyenin hukukunu zarara uğratan dikkat çekici maddelerdendir.

1918 yılında belediye çayırında üretilen buğday ve akdarı miktarlarıyla fiyatları düzenli olarak defterlere kaydedilmediği gibi satılan hububat bedelinin hemen ve peşin olarak tahsil edilmeyerek bakayada bırakılması ve bu hububattan bir kısmının belediye başkanının 
zimmetinde olması belediye kanununun ek maddesi gereğince takibatı gerektirdiğinden hemen gereğinin yapılarak sonucunun bildirilmesi gerekir.

Bu nedenle, bu derece kanuna aykırı muamelelere meydan veren Muğla Belediye Reisi Ragıp Bey'in hemen azledilerek değiştirilmesi, belediye hesaplarının incelenmesi, meydana geldiği açıklanan suç ve eksikliklerin sslahı ve tamamlanması, bundan böyle bu tür suiistimallere mahal verilmeyerek belediye işlemlerinin kanuna uygun şekilde yürütülmesinin sağlanması ve ortaya çıan sonuçlardan bilgi verilmesi gerektiği tavsiye olunur (BOA, DH.UMVM, Dos. 1, no.92, Lef.14).

\section{SORUŞTURMA RAPORU İLE İLGİLI DEĞERLENDİRME}

Mülkiye müfettişinin soruşturma raporunda, içeriğine ancak işletme uzmanı, mahalli idareler kontrolörü veya belediye yönetiminde uzmanlaşmış kişilerin vâkıf olabileceği türden terim, muamele ve faaliyet tanımları yer aldığından uzmanlık alanımızdan da biraz uzak olması nedeniyle raporu teknik anlamda değerlendirmemiz pek de mümkün görünmemektedir. Makbûzât sütununa gelir kaydetme, icar açık arttırma karardâdesi, masraf senetlerine verile muamelesi yapma, ihale sırasında isteklilere el çektirilme vs. gibi birçok tanımlama ve terim, iddialar ve savunma üzerine analiz yapabilmemizi güçleştirmektedir.

Ancak mülkiye müfettişinin raporunda yer alan "...kâtiplerle ahaliden belediyeyi ziyaret eden olmaz, sadece kendisinin görüştü̈̆̈̈ memurlar gelirler, hatta bunlardan bazılar bile makamında bulamazlar", "...bu nedenle satın alındığı gösterilen iki buçuk kilo sigara hakikaten bu miktar ise her halde iki kilo kadarı aylarca içmek üzere kendisinde kalmıştır, nitekim gelecek aydan sonra bir süre birinci nev' sigara içer", ". . hatasını örtmek için işlemler sırasında her günkü teftişlerde bizzat ifa ettiğini öne sürmesi tamamen yalandır, çünkü şimdiye kadar yapılan kaldırımlar inşa edilirken bir defa olsun oradan geçmedi" gibi değer yüklü ve ön yargi ile yaklaşım izlenimi veren ifadeler dikkati çekmektedir.

Belediye Başkanı Ragıp Bey'in savunmasında yer alan müfettişe yönelik “zatınıza verilen bilgilerin gerçeğe aykırı ve kişisel garazdan ibaret olduğunu arz eder ilgili meblağın kaydının incelenmesini sağlamak üzere sandık yeumiye defterini de takdim kllabilirim" şeklindeki ifadesinden de belediye başkanı hakkında yapılan kasıtlı bir şikâyet veya ihbar üzerine soruşturma açıldığı tahmin edilmektedir.

Müfettiş raporundaki iddialar ve belediye başkanının raporla ilgili savunması birlikte değerlendirildiğinde müfettiş ve belediye başkanının birbirini tanıdığı, müfettişin, başkan hakkında pek de iyi niyet taşımadığı izlenimi edinilmektedir. Müfettişin, belediye başkanının belediye parasıyla satın alınan kuzulardan üçünü kendi evine aldığı, İtalyan heyete verilen yemeğin malzemelerinden artmış olabileceği, bir kısmının da başkanın evinde kaldığı şeklindeki görüş ve düşüncesine de ihtiyatla yaklaşılması gerektiği kanısındayız.

Çünkü yukarıda ifade edildiği gibi ticari işletmeleri olan, şehrin bir kısmına hizmet verebilecek düzeyde elektrik üretebilen varlıklı birinin, belediye kaynaklarından ufak tefek nemalanmaya yönelik teşebbüslerle itibarını, güvenilirliğini, saygınlığını zedeleyebileceğini düşünmemizi güçleştirmektedir.

Dâhiliye Nezareti'nin, mülkiye müfettişinin raporuna istinaden Belediye Başkanı Ragıp Bey'in azledilip yerine başkasının seçilmesini önermesine rağmen 1928 yılına kadar meclis üyeleri tarafından her dönem için yeniden seçilip atanması da hakkındaki usulsüzlük ve yolsuzluk iddialarının doğruluğu ve geçerliliği hakkında tereddütler yaratmaktadır. Gerçi onu görevinden alma durumunda olan Mutasarrıf Ethem Fehmi Bey 19 Mart 1920 tarihinde yapılan 
BMM seçimlerinde Muğla'dan milletvekili seçilip ayrılmışsa da ${ }^{17}$ onun yerine tekrar Menteşe Mutasarrıfı atanan Müştak Bey'in nezaretin azil önerisini uygulamaya koyması beklenirdi.

Hatırlanacağı üzere 5 Ekim 1877 tarihli Vilâyât Belediye Kanunu'nun 4. maddesi gereğince belediye başkanı belediye meclisinin seçilmiş üyeleri tarafından seçilerek atanıyor, hatta sonradan yapılan bir değişiklikle üst makamların seçilen başkanın memuriyetini onaylama yetkisi bile kaldırılıyordu. Diğer bir ifadeyle Ragıp Bey'i azletme yetkisi vali veya mutasarrıfta idi.

Belediye başkanının yeni Mutasarrıf Müştak Bey ile 1914-1916 yılları arasında ve Milli Mücadele yıllarında beraber çalışmış olması ve birbirilerini tanıyor olmaları azle engel olmuş olabilir mi şüphesini akla getirse de 1928 yılına kadar Muğla'da görev yapacak olan tüm valilerle birlikte seçilmiş bir başkan olarak çalışmaya devam etmesi, üstelik Mustafa Kemal Atatürk'ün ve cumhuriyetin, hakkında en küçük bir şaibe olan yönetici veya bürokrata hoşgörü gösteremeyeceği bir dönemde görevini sürdürmesi çalışmanın başında dile getirdiğimiz Kuvâyı Milliyeciliği mi cezalandırılmak istendi şeklindeki şüphemizi güçlendirir niteliktedir.

\section{SONUÇ}

1871 yılında kurulmuş olan Menteşe Belediyesi'nin kurumlaşma çalışmaları ilk başkan Süleyman Efendi döneminde tamamlanmış, alt yapı, imar, sosyal tesis, çevre düzenlemesi vs. gibi hizmetler sonraki başkanlar döneminde de geliştirilerek sürdürülmüştür. Menteşe adı 24.10.1926 tarih ve 4248 sayılı kararname ile Muğla adını almıssa da (Düstur, Tertip,3, C. 7, s.1681) Cumhuriyet öncesi dönemde Muğla Belediyesi adının yaygın olarak kullanıldığı Osmanlı Arşivi belgelerinde yoğun şekilde görülmektedir.

Cumhuriyet öncesi döneminde genellikle küçük ve denk bir bütçeye sahip olan Muğla Belediyesi'nin gelir kaynaklarını, vergiler, nakdi cezalar, belediyeye ait tarla, çayır, dükkân vs gibi gayrimenkullerin kira bedelleri, giderlerini de personel maaşları, temizlik, aydınlatma masrafları ve sosyal yardım harcamaları oluşturmuştur.

1914-1928 yılları arasında belediye başkanlığı yapan Mehmet Ragıp Zorbazzade döneminde şehir elektrikle tanışmış, I. Dünya Savaşı ve Milli Mücadele'nin zorlu yılları en az sıkıntı ile atlatılmaya çalışılmıştır. Başkan Ragıp Bey, hem Menteşe Kuvâ-yı Milliyesi'nin örgütlenmesindeki hem Milli Mücadele'nin başarılmasındaki katkılarıyla Muğla tarihinde önemli bir yere sahip olmuştur.

Hakkında 1920 yılı Şubatında açılan usulsüzlük ve yolsuzluk soruşturması sonucunda Dâhiliye Nezareti'nin görevden azledilmesi gerektiği görüşüne rağmen görevini 1928 yllına kadar sürdürmüş olması, soruşturma dosyasındaki iddia ve suçlamaların ciddiyeti ve doğruluğuna ilişkin şüphelerin oluşmasına neden olmuştur.

İddia ve suçlamaların yerinde ve isabetli olup olmadığını, başkanın suçlu kabul edilip edilemeyeceğini takdir etmek tarihçinin görevi olmamakla beraber, Dâhiliye Nezareti'nin ifadesiyle kanunlara aykırı muamelelere meydan veren bir başkanın 1928 yılına kadar seçilmiş olarak görevini sürdürmesi karşısında iddiaların Mehmet Ragıp nezdinde Kuvâ-yı Milliyeyi güçsüz ve etkisiz bırakmaya yönelik bir girişim olup olmadığı sorusunu sormaktan da alıkoyamamaktadır.

Mehmet Ragıp, Cumhuriyet dönemiyle birlikte belediye hizmetlerinin yanı sıra cumhuriyetin, Atatürk ilke ve inkılâplarının Muğla'da tanınıp kök salması için de çaba

17 Ethem Fehmi Bey'in Menteşe Mutasarrıflı̆̆ı'ndan azil tarihi 15 Ağustos 1920'dir (BOA, BEO, Dos.4647. no.348452). 
göstererek, Muğla ve Milli Mücadele tarihindeki müstesna yerini almıştır. Milli Mücadele ve Cumhuriyetin ilk yıllarında uzun yıllar beraber çalıştığı ve onun belediye başkan yardımcılığını yapan İskender Alper Bey (BCA, 30.10.0.0/197.347.5, Lef.1,2) 1931-1950 yılları arasında Muğla Belediye Başkanlığı yaptığı dönemde ${ }^{18}$ ustasından öğrendiği deneyimlerini uygulamaya koymuştur.

\section{EXTENDED ABSTRACT}

Local government models and units have been created to meet the municipal needs of the residents who live in cities. With the development of these models and units throughout the history, which may differ from country to country and from society to society, today's modern municipality understanding has been reached.

With the reform movement that changed the Ottoman traditional concept of municipality, the idea of modern municipality and contemporary local government started to develop and after the legal arrangements regarding the provinces and municipalities in 1864, 1867 and 1871, the first municipal organization was established in Muğla / Menteşe province in 1871. Since then, many people served as mayors until the Republican era, and with the declaration of the Republic, a new process started in relation to the concept of municipality.

Between 1914 and 1928, Mehmet Ragıp Zorbazzade served as the Mayor of Muğla. In 1920, he was subjected to an investigation of irregularity and corruption on the grounds of excessive spending, irregular consumption, off-the-books and incomplete transactions, extra-budgetary spending, and actions taken before and without a parliamentary decision. This investigation is the subject of the current study. During the research process on the subject, since the necessary information and documents could not be found in the archive and documentation centres of the municipality and other local institutions, mainly the Ottoman Archive documents were used.

Ragip Zorbazzade answered all claims and accusations of the civil inspector during the investigation process, presented records and documents related to expenditures, and cash register assets. After the investigation file was evaluated in the Ministry of Internal Affairs, a dismissal decision was made on September 17, 1920, on the grounds that he made illegal payments outside the budget, did not report his account transactions accurately, did not conduct auctions and bids duly, damaged municipal law and made illegal transactions.

It was also noteworthy that despite the dismissal decision of the Ministry of Internal Affairs, Ragip Zorbazzade was not dismissed and re-elected and re-appointed by the parliament in every period until 1928. This also caused some doubts about the investigation because the governor of the period during which the practices and actions that led to the investigation were carried out was Hilmi Bey, but the investigation was opened after the appointment of the new governor Ethem Fehmi Bey, who was appointed during the period when the Kuvâ-yı Milliye (The National Forces) was organized and getting stronger.

Ragıp Bey was one of the members of the Kardeş Yurdu Club, which made significant contributions to the emergence and development of the Muğla Kuva-yı Milliye, pioneered the establishment of the Menteşa Müdafaa-i Vatan Cemiyeti, which was established on May 17, 1919 and participated in local congresses in İzmir and Nazilli as the Muğla representative in order to discuss the issue of controlling the preparations to be made behind the front line by a single

18 İskender Alper'in 1931, 1934, 1938, 1942 ve 1946 yıllarında belediye meclisi tarafından seçildiği belediye başkanlığ1 görevinin cumhurbaşkanlığı tarafından onaylanma süreçleri için bkz (BCA, 30.11.1.0/62.11.15, Lef.1-4; BCA, 30.11.1.0/91.40.13; BCA, 30.11.1.0/126.43.16; BCA, 30.11.1.0/158.37.5; BCA, 30.11.1.0/184.21.6). 
authority and the strategies to be followed by the Western Anatolian Kuvâ-yı Milliye; thus, he was a national hero. Therefore, with the investigation, was it intended to break its support for the National Struggle?

Ragip Bey, who continued his duty in the first years of the Republic despite the investigation and dismissal decision, became an important figure in the history of Muğla and the National Struggle with the efforts he made for the recognition of the republic and Atatürk Revolutions in Muğla as well as for the effective provision of the municipal services. He died in 1928 and was buried in Edirnekapı Martyr's Cemetery. 


\section{KAYNAKÇA}

1. Arşivler

a. Başbakanlık Osmanlı Arşivi

Y.PRK.UM, (Yıldız Perakende Umumi Evrakı)

DH.ŞFR, (Dâhiliye Nezareti Şifre Evrakı)

ŞD, (Şûrâ-yı Devlet Evrakı)

DH.MKT, (Dahiliye Nezareti Mektûbî Kalemi)

DH.TMIK.S, (Dahiliye Nezareti Tesri-i Muamelat ve Islahat Komisyonu Islahat)

BEO, (Bâb-1 Âlî Evrak Odası)

DH.UMVM, (Dahiliye Nezareti Umûr-u Mahalliye ve Vilâyât Müdüriyeti Evrakı)

DH.ID, (Dahiliye Nezareti İdare Evrakı)

İ.DUİT, (İrade Dosya Usulü)

EUM.AYŞ, (Dahiliye Nezareti Emniyet-i Umumiye Asayiş Kalemi Evrakı)

DH.KMS, (Dahiliye Nezareti Kalem-i Mahsus Evrakı)

BOA, Y.PRK.UM, Dos.79, no.122.

BOA, DH.ŞFR, Dos.631, no.17.

BOA, DH.ŞFR, Dos. 383, no.85.

BOA, DH.ŞFR, Dos.62, no.311.

BOA; DH.ŞFR, Dos. 515/101.

BOA, DH.ŞFR, Dos.63, no.41.

BOA, DH.ŞFR, Dos.516/79.

BOA, İ.DUiT, Dos.42, no.29.

BOA, ŞD, Dos.1449, no.29.

BOA, ŞD, Dos.1449, no.38.

BOA, ŞD, Dos.1449, no.44.

BOA, DH.MKT, Dos.137, no.49.

BOA, DH.MKT, Dos.1140, no.47.

BOA, DH.TMIK.S, Dos.72, no.65

BOA, BEO, Dos.4596, no.344688.

BOA, BEO, Dos.4419, no.331423.

BOA, BEO, Dos.4647. no.348452.

BOA, BEO, Dos. 4576, no.343138.

BOA, DH.UMVM, Dos. 90, no.23, Lef.1.

BOA, DH.UMVM, Dos.1, no. 92, Lef.1,2,3,4,5,6,7,8,9.

BOA, DH.ID, Dos.12, no.17

BOA, EUM.AYŞ, Dos.6, no. 52, Lef.3,4.

BOA, EUM.AYŞ, Dos.3, no. 64, Lef.4.

BOA, DH.KMS, Dos.53, no.54.

BOA, DH.KMS, Dos.53, no.67.

BOA, DH.KMS, Dos.53-3, no.67, Lef.1,2.

b. Başbakanlık Cumhuriyet Arşivi

30.10, Başbakanlık Muamelât Genel Müdürlüğü Evrak1

30.11, Müşterek Kararnameler (Kronolojik) (1923-1975)

BCA, 30.10./197.347.5, Lef.1,2.

BCA, 30.11./62.11.15, Lef.1-4.

BCA, 30.11./91.40.13.

BCA, 30.11./126.43.16.

BCA, 30.11./158.37.5.

BCA, 30.11./184.21.6.

2. Kitaplar

Akça, B. (2002). Sosyal-siyasal ve ekonomik yönüyle Muğla (1923-1960). Ankara: Atatürk Araştırma Merkezi Yay.

Aybars, E. (1995). Türkiye Cumhuriyeti tarihi I, Ankara: Zeus Kitabevi. 
Çanlı, M. \& Türkeş, Ü. (1999). Datça (Reşadiye) Kuvâ-yı Milliyesi. Ankara: Atatürk Araştırma Merkezi yay.

Devellioğlu, F. (1990). Osmanlıca-Türkçe ansiklopedik lügat. Ankara: Aydın Kitabevi.

Düstur, (1944). Tertip, 3, (C. 7), Ankara.

Eroğlu, Z. (2011). Muğla tarihi. Muğla: Muğla Belediyesi Kültür Yay.

Gökbel, A. (1964). Milli Mücadelede Aydın. Aydın: Coşkun Matbaası.

Hakses, A.R. (2010). Muğla Menteşe Büyü̈leri. Adnan Çevik (Haz.), Muğla: Muğla Valiliği İl Müftülüğü Yay.

Atatürk, (2012). Nutuk 1919-1927. Ankara: Atatürk Araştırma Merkezi Yay.

Ökmen, M. \& Özer, B. (2013). Türkiye' de Yerel yönetimler: yapısal-işlevsel görünüm, sorunlar ve arayışlar. M. Ökmen \& F. Elma, (Ed.), Türk Dünyasında Yerel Yönetimler, 15-60.

Türkeş, Ü. (1973). Kurtuluş Savaşı'nda Muğla. İstanbul.

Türkeş, Ü. (2019a). Cumhuriyeti kucaklayan Muğla. Muğla: Muğla Büyükşehir Belediyesi Kültür Yayınları.

Türkeş, Ü. (2019b). Cumhuriyeti arayan Muğla. Muğla: Muğla Büyükşehir Belediyesi Kültür Yayınları. Umar, B. (2002). Yunanlıların ve Anadolu Rumlarının anlatımıyla İzmir savaşı. İstanbul: İnkılap Kitabevi.

Türkmen, Z. (2020). Mütareke ve işgalden Milli Mücadele'ye Mustafa Kemal Paşa 1918-1920. İstanbul: Yeditepe Yay.

3. Makaleler

Aktüre, S. (2006).19. Yüzyılda Muğla. Tarih İçinde Muğla. (Tekeli, İ. Der.), Muğla, 34-113.

Aslantürk, A.Y. (2018). Tanzimat sonrası Osmanlı Şehirlerinde taşrada yerel hizmetlerin yeniden örgütlenmesi. Aksaray Üniversitesi İktisadi ve İdari Bilimler Fakültesi Dergisi, 10(4), 141-149.

Çelebi, M. (1993). Menteşe Gazetesi. Toplumsal Tarih, 19(112), 222-225.

Deniz, A., Akarçay P. \& Karakaş, A. (2017). Osmanlıda belediyeciliğin gelişimi ve modernleşme çabaları. Akademik Bakış Dergisi, 64, 314-325.

Kallek, C. (2007). Okka. İslam Ansiklopedisi, (C. 33, s.338-339). İstanbul: Türkiye Diyanet Vakfı Yay.

Mete, Z. (2005). Muğla. İslam Ansiklopedisi, (C. 30, s.377-381). İstanbul: Türkiye Diyanet Vakfı Yay.

Ortaylı, İ. (1992) Belediye. İslam Ansiklopedisi (C. 5, s.398-402). İstanbul:Türkiye Diyanet Vakfı Yay.

Tekeli, İ. (1993). 1923-1950 Döneminde Muğla' da olan gelişmeler. Tarih İçinde Muğ la, (Tekeli İ. Der.), Muğla, 114-187.

\section{Tezler}

Eken, H. (1995). Milli Mücadele'de Vali (Kapancızade) Hamid Bey (Yayımlanmamış doktora tezi). Atatürk Üniversitesi, Erzurum.

Yazıcı, N. (1985). Canik Sancağı'nda Pontusçu faaliyetler (1918-1922) (Yayımlanmamış Doktora Tezi). Atatürk Üniversitesi, Erzurum.

Zeki, O. (2018). Birinci Türkiye Büyük Millet Meclisi'nde bağımsız mebuslar ve yasama çalışmaları (19201923) (Yayımlanmamış Yüksek Lisans Tezi), Hacettepe Üniversitesi, Ankara. 